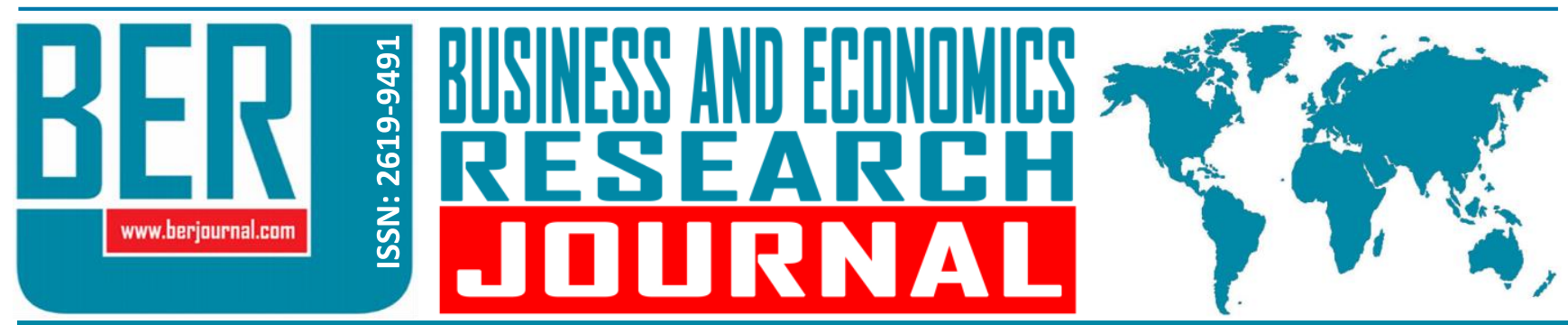

Business and Economics Research Journal Vol. 11, No. 3, 2020, pp. 681-702 doi: 10.20409/berj.2020.277

\section{Döviz Kurları ile BİST Turizm Endeksi Getirileri Arasındaki Volatilite Yayılım Etkisinin Belirlenmesi ${ }^{1}$}

\author{
Serdar Yaman ${ }^{\mathrm{a}}$, Turhan Korkmaz
}

Öz: Bu araştırmanın amacı döviz kurları ile BiST Turizm Endeksi (XTRZM) getirileri arasındaki volatilite yayılım etkisinin ekonometrik yöntemlerle belirlenmesidir. Bu bağlamda, konvertibilitesi yüksek para birimleri olan USD, EUR, JPY ve GBP ve Türkiye'ye yüksek miktarda turist gönderen bir ülke olan Rusya'nın para birimi olan RUB ile BiST XTRZM getirileri arasındaki volatilite yayılımı çok değişkenli GARCH modellerinden olan Diagonal VECH-GARCH yöntemi ile analiz edilmiştir. Elde edilen bulgular, XTRZM ve Döviz kurlarında volatilitenin sürekli etkilere sahip olduğunu ve volatilite kümelenmelerinin oluştuğunu göstermektedir. Uygulanan Diagonal VECH-GARCH modeli sonuçlarına göre, USD/TRY, EUR/TRY, GBP/TRY ve RUB/TRY kurları ile XTRZM Endeksi getirileri arasında istatistiki olarak anlamlı bir volatilite yayılımı olduğu tespit edilmiştir. Analiz sonuçlarına göre, JPY/TRY ile XTRZM Endeksi getirileri arasında ise volatilite yayllımına ilişkin istatistiki olarak anlamı bir sonuca ulaşılamamıştır. Çalışma sonucunda elde edilen bulgular, özellikle döviz kurlarındaki oynaklı̆ıın artı̆ı dönemlerde XTRZM endeksi getirilerinde de volatilitenin yükseldiğine işaret etmektedir.

\section{Determination of Volatility Spillover Effect Between Exchange Rates and BIST Tourism Index Returns}

\begin{abstract}
The purpose of this study is to determine the volatility spillover effects between exchange rates and BIST Tourism Index (XTRZM) returns by using econometric methods. In this concept, the volatility spillover between USD, EUR, JPY, and GBP as highly convertible currencies and RUB, the currency of Russia which is a country that sends large amounts of tourists to Turkey, and BIST XTRZM returns has been analyzed by Diagonal VECH-GARCH method which is one of the multivariate GARCH models. The findings show that volatility has constant effects on XTRZM and exchange rates and volatility clusters are formed. According to the results of Diagonal VECH-GARCH model, statistically significant volatility spillover effects between USD/TRY, EUR/TRY, GBP/TRY and $R U B / T R Y$ exchange rates and XTRZM Index returns have been determined. According to the results of the analysis, there is no statistically significant volatility spillover effect between JPY/TRY and XTRZM Index returns. The findings of the study indicate that volatility in XTRZM index returns increased especially during periods of volatility in exchange rates.
\end{abstract}

Anahtar Sözcükler: Döviz Kurları, BisT Turizm Endeksi, Volatilite Yayılımı, MultiGARCH Modeller

JEL: C58, F31, G10

$\begin{array}{ll}\text { Geliş } & : 03 \text { Mart } 2020 \\ \text { Düzeltme } & : 05 \text { Mayıs } 2020 \\ \text { Kabul } & : 03 \text { Haziran } 2020 \\ \text { Tür } & : \text { Araştırma }\end{array}$

Keywords: Exchange Rates, BIST Tourism Index, Volatility Spillover, Multi-GARCH Models

JEL: C58, F31, G10

$\begin{array}{ll}\text { Received } & : 03 \text { March } 2020 \\ \text { Revised } & : 05 \text { May } 2020 \\ \text { Accepted } & : \text { 03 June } 2020 \\ & \\ \text { Type } & : \text { Research }\end{array}$

Type : Research

a Lec., Sirnak University, Cizre Vocational School, Department of Accounting and Taxation, Sirnak, Turkiye, serdaryaman@sirnak.edu.tr (ORCID ID: 0000-0002-8316-0805)

b Prof., PhD., Mersin University, Faculty of Economics and Administrative Sciences, Department of Business Administration, Mersin, Turkiye, tkorkmaz@mersin.edu.tr (ORCID ID: 0000-0001-5468-2279) 


\section{Giriş}

Finans teorisinde getiri kavramı ile birlikte yatırımların en önemli iki kavramından biri olan risk kavramı, beklenen getirinin gerçekleşen getiriden sapma olasılığı şeklinde tanımlanmaktadır (Yıldız, 2016: 84). Modern portföy teorisinde, yatıımcıların yatırım kararı alırken rasyonel davranışlar sergiledikleri varsayılmaktadır. Bu durum, yatırımcıların belirli bir getiriyi minimum risk düzeyinde hedeflemeleri, belirli bir risk düzeyinde ise maksimum getiriyi hedeflemeleri şeklinde ifade edilebilir. Dolayısıyla yatırımcıların yatıım kararı alırken finansal yatıım araçlarının getirilerinin yanı sıra risklerini ve birbirleri üzerine olan etkilerini de dikkate aldıkları varsayılmaktadır. Bu bağlamda, finansal piyasalarda yatırım araçlarının risk düzeylerinin doğru tahmin edilmesi ve bir yatııım aracında meydana gelen değişimlerin diğer yatırım araçlarında yarattığı etkilerin tespit edilmesi önem arz etmektedir.

Finansal piyasalarda meydana gelen beklenmedik olaylar yatırım araçlarının fiyatlarında önemli düşüş veya yükselişlere neden olabilmektedir. Yatııım araçlarının fiyatlarında gözlemlenen söz konusu ani değişimler, belirli bir zaman serisi içerisinde ortalamadan önemli ölçüde sapmaya neden olmaktadır (Topaloğlu, 2019: 576). Finansal piyasalarda varlık fiyatlarındaki dalgalanmaların büyüklüğünü ve sıklığı ifade eden volatilite, piyasalarda belirsizlik ve değişkenliğe neden olduğundan risk unsuru oluşturmakta ve dolayısıyla yatırımcıların geleceğe yönelik fiyat ve getiri tahminlerini ve yatırım kararlarını zorlaştırmaktadır. Piyasalara gelen şokların diğer piyasalara yansıması şeklinde tanımlanabilecek volatilite yayılımı ise, pay veya endeks fiyatları ve döviz kurları gibi finansal serilerin sahip olduğu ortak hareketlerin neden olduğu bir süreçtir (Gökbulut, 2017: 142). Volatilite yayılımı genellikle birden fazla piyasada yatırım yapan yatırımcıların portföy yatırımı kararlarından etkilenen ortak fiyat değişimlerinden kaynaklanır (Çiçek, 2010: 2). Bir finansal piyasada meydana gelen şokun diğer bir piyasanın volatilitesini etkileyip etkilemediği, yatırımcıların yatırım kararlarında belirleyici bir faktör olabilmektedir. Bu durum da piyasalar arasındaki volatilite yayılım etkilerinin tespit edilmesini önemli kılmaktadır.

Finansal zaman serilerinin volatilite kümelenmesi, aşırı basıklık ve kaldıraç etkisi gibi sabit varyans varsayımını ortadan kaldıran unsurlara sahip olmaları nedeniyle literatürde volatilite modellemesi için sıkıkla koşullu değişen varyansları esas alan ARCH/GARCH (Autoregressive Conditional Heteroskedasticity/Generalized Autoregressive Conditional Heteroskedasticity) modelleri kullanılmıştır. Piyasalar arasındaki volatilite yayılım etkisinin tespit edilmesi için ise literatürde en sık kullanılan modeller çok değişkenli koşullu değişen varyans modelleri olan Multi-GARCH modelleridir.

Döviz kuru piyasaları, oynaklığın yüksek düzeylerde gözlemlendiği, şokların yüksek sıklıklarla meydana geldiği, riskin yüksek olduğu piyasalardır. Özellikle Bretton Woods anlaşmasının sona ermesiyle girilen dalgalı kur rejimi, döviz kuru piyasalarının en riskli piyasalardan biri olmasına neden olmuştur. Yüksek volatiliteye sahip döviz kuru piyasaları, ülkelerin pay piyasalarında da volatiliteye neden olabilmekte, belirsizliği ve riski artıran nedenlerden biri olabilmektedir. Döviz kurları ve pay piyasaları arasındaki ilişkileri ulusal piyasalar üzerinden inceleyen Dornbusch ve Fischer (1980)'e göre, döviz kurlarından meydana gelen yükselişler, firmaların rekabetçiliklerini ve dolayısıyla ihracatlarını artıracağından firmaların gelir düzeylerini ve pay fiyatlarını yükselecektir. Literatürde geleneksel yaklaşım olarak bilinen bu yaklaşım, döviz piyasalarında meydana gelen şokların pay piyasalarına da yansıyacağı, dolayısıyla iki piyasa arasındaki volatilite yayılım etkisinin döviz piyasalarından pay piyasalarına doğru olacağını öne sürmektedir. Branson (1981)'a göre ise, pay piyasalarındaki yükselişler yatırımcıları yabancı varlıklarını satarak daha fazla ulusal varlık satın almaya yönlendireceğinden döviz piyasalarında düşüşler meydana gelecektir. Bu yaklaşım literatürde portföy dengesi yaklaşımı olarak bilinmekte ve pay piyasalarında meydana gelen şokların döviz piyasalarına yansıdığı, dolayısıyla iki piyasa arasındaki volatilite yayılım etkisinin pay piyasalarından döviz piyasalarına doğru gerçekleştiğini öne sürmektedir.

Turizm sektörü ülkelerin ekonomik kalkınmalarına özellikle gelir getirme ve döviz sağlama fonksiyonlarıyla ön plana çıkmaktadır (Çelik Oğuz ve Topbaş, 2011: 2). Teorik olarak turizm sektörü performansına etki eden ve sektörü yönlendiren birçok faktör bulunmakla birlikte, en fazla etkiye sahip faktörlerin ekonomik olduğu söylenebilir (Şen ve Şit, 2015: 6752). Turist sayısı, reel yatırımlar, ülkelerin turizm sektörüne verdiği teşvikler, küresel ekonomik gelişmeler, uluslararası gelir, turistik ürün fiyatları, hizmet 
çeşitliliği, reklam ve politik istikrarın yanı sıra enflasyon, büyüme ve döviz kurlarındaki değişimler gibi makroekonomik faktörler de ekonomik kalkınma ve gelişim için önem arz eden turizm gelirlerinin belirleyicileri arasında yer almaktadırlar (Öncel vd., 2016: 128). Turizm faaliyetleri, yapısı gereği uluslararası hizmet faaliyetleri arasında yer almakta ve hizmet ihracatının en önemli kollarından birini oluşturmaktadır (Seyidoğlu, 2009: 312). Dış dengenin sağlanması için ülkeler dövize intiyaç duymaktadırlar. Turizm faaliyetleri, ihracat gelirlerinden sonraki en önemli döviz sağlayıcı faaliyetlerdir. Geleneksel teoriye göre, ülke para birimlerinin değerindeki değişimler ile ülkelerin sahip oldukları uluslararası ticaret akımları arasında önemli bir ilişki söz konusudur. Yabancı turistlerin bir ülkede gerçekleştirdiği harcamalar, o ülkenin hizmet ihraç etmesi anlamına gelmektedir. Yabancı turistlerin söz konusu harcamaları döviz kurlarından etkilenebilmektedir. Döviz kuru ve pay piyasası arasındaki ilişkiyi ifade eden yaklaşımlardan olan geleneksel yaklaşım turizm sektörü açısından düşünüldüğünde, yerli paranın değerinde meydana gelen düşüşlerin yabancı turistleri cezbedeceği ve yabancı turist sayısı ve turizm gelirlerinde artış meydana geleceği söylenebilir. Turizm firmalarının gelirlerinde meydana gelen değişimlerin pay fiyatlarına da yansıyacağı düşünüldüğünde, döviz kurlarındaki değişimlerin turizm firmalarının pay fiyatları üzerinde etkili olması beklenmektedir. Döviz kuru kadar, döviz kuru volatilitesi de turizm gelirleri üzerinde etkili olabilmektedir. Döviz kurlarındaki yüksek risk ve belirsizlik yabancı turistlerin turizm harcaması davranışlarını, dolayısıyla turizm firmalarının gelirlerini ve piyasa değerlerini etkileyebilmektedir (Kaya ve Çakır Çömlekçi, 2013: 83).

Birçok ülkede olduğu gibi Türkiye'de de turizm faaliyetleri önemli gelir kaynağı ve döviz sağlayıcısı faaliyetler arasında bulunmaktadır. Türkiye'nin Akdeniz ve Ege bölgeleri başta olmak üzere çeşitli bölgelerine özellikle her yıl yaz aylarında milyonlarca turist gelmekte ve önemli miktarda döviz bırakmaktadırlar. Her yıl Türkiye'ye gelen turist sayısı ve turizm faaliyetlerinden sağlanan gelir çeşitli nedenlerle değişmektedir. Değişen gelir düzeyinin turizm firmalarının piyasa değerlerine de yansıması beklenmektedir. Türk lirasının özellikle Amerikan doları (USD) ve Euro (EUR) gibi rezerv para birimleri ve ülkeye yüksek sayıda turist gönderen diğer ülkelerin para birimleri karşısında, genel ekonomik nedenler ve politik nedenler başta olmak üzere çeşitli nedenlerle önemli ölçüde ani düşüşler ve yükselişler yaşaması, diğer bir ifadeyle dalgalanma göstermesi turizm gelirlerindeki söz konusu değişimlerin nedeni olabilmektedir. Bu bağlamda, döviz kurlarındaki dalgalanmaların turizm firmalarının gelirlerinde, pay fiyatlarında ve pay getirilerinde yarattığı etkilerin incelenmesi önem arz etmektedir.

Bu çalışmada, çeşitli döviz kurları ile BiST Turizm Endeksi (XTRZM) getirileri arasındaki volatilite yayılım etkisinin ekonometrik yöntemlerle belirlenmesi amaçlanmıştır. Bu amaç doğrultusunda çalışmanın teorik altyapısının yer aldığı giriş bölümünün ardından ikinci bölümde, döviz kurları ile pay getirileri arasındaki volatilite yayılımını inceleyen ulusal ve uluslararası literatür incelemesine yer verilmiştir. Üçüncü bölümde, oluşturulan veri seti ve analizlerde kullanılan yöntemler anlatılmış, cevaplanan araştırma sorularına yer verilmiştir. Dördüncü bölümde, çalışmanın bulgularına yer verilmiş ve yorumlanmıştır. Çalışma, elde edilen sonuçlar ışığında genel değerlendirme ve önerilerin yer aldığı sonuç bölümü ile sonlandırılmıştır.

\section{Literatür İncelemesi}

Finansal serilerin volatilitelerinin diğer bir ifadeyle oynaklıklarının modellenmesi ve seriler arasında volatilite yayılım etkisinin belirlenmesine ilişkin gerek ulusal gerekse de uluslararası literatürde birçok çalışma söz konusudur. Literatürde farklı makroekonomik faktörlerin kendi aralarındaki volatilite yayılımını inceleyen çalışmalar olmakla beraber makroekonomik faktörlerden pay piyasalarına doğru olan volatilite yayılımının incelendiği çalışmaların yoğunlukta olduğu gözlenmektedir. Özellikle pay, endeks ve döviz gibi risk düzeyi yüksek finansal varlıkların volatilitelerinin modellenmesi ve aralarındaki volatilite yayılım etkisinin belirlenmesine yönelik çalışmaların son yıllarda arttığı gözlemlenmektedir. Doğrudan döviz kuru volatilitesi ile turizm firmaları pay getirisi volatilitesi arasındaki yayılım etkisini inceleyen çalışmaların ise sınırlı kaldığı görülmektedir. Literatür araştırması kapsamında incelenen çalışmalar, kullandıkları yöntemler ve elde ettikleri sonuçlar itibariyle aralarındaki benzerlikler ve farklıııklar dikkate alınarak aşağıda verilmiştir.

Döviz kuru volatilitesi ile pay getirisi volatilitesi arasındaki yayılım etkisini inceleyen çalışmalardan Darbar ve Deb (1999), çok değişkenli GARCH modellerini kullanarak ABD emtia, döviz, tahvil ve pay piyasası arasındaki oynaklık ilişkilerini 1984-1993 dönemine ait günlük veriler ile incelemiş ve pay getirileri ile tahvil, tahvil ile döviz ve döviz ile emtia piyasaları arasında volatilite yayılım etkisinin varlığına yönelik kanıtlara 
ulaşmıştır. Kanas (2000) ise, ABD, Birleşik Krallık, Japonya, Kanada, Fransa ve Almanya'ya ilişkin 1986-1998 dönemine ait günlük veriler ile pay piyasası ve döviz kurları arasındaki volatilite yayılımını EGARCH modeli ile incelemiş ve Almanya dışındaki beş ülke için pay piyasasından döviz kurlarına doğru istatistiki olarak anlamlı volatilite yayılım etkisinin olduğu, volatilite yayılım etkisinin tüm ülkeler için simetrik özellik gösterdiği ve döviz kurlarından pay piyasalarına doğru hiçbir ülke için istatistiki olarak anlamlı volatilite yayılımı etkisinin olmadığına yönelik bulgular elde etmiştir. Yung Yang ve Chyi Doong (2004) G-7 ülkelerinde pay piyasası ile döviz kurları arasındaki volatilite yayılımını EGARCH modelini kullanarak incelemişlerdir. Çalışmanın sonucunda, Fransa, İtalya, Japonya ve ABD için pay piyasalarından döviz kurlarına doğru istatistiki olarak anlamlı ve asimetrik volatilite yayılım etkisinin bulunduğu, pay fiyatlarındaki oynaklıkların gelecekteki döviz kurlarındaki oynaklıkları anlamlı şekilde etkileyeceği, fakat döviz kurlarındaki oynaklıkların pay fiyatlarındaki oynaklıklar üzerinde daha az etkisinin olacağı tespit edilmiştir. Multi-GARCH BEKK yöntemi ile Borsa İstanbul ulusal ve sektör endeks getirileri, tahvil piyasası ve döviz kuru arasındaki volatilite yayılım etkisinin incelendiği çalışmada Alkan ve Çiçek (2020), tüm değişken ikilileri arasında anlamlı volatilite yayılım etkilerinin bulunduğuna yönelik bulgular elde etmişlerdir.

Döviz kuru volatilitesi ile pay getirisi volatilitesi arasında anlamlı yayılım etkileri tespit edilen diğer bir çalışma ise Adjasi, Harvey ve Agyapong (2008) çalışmasıdır. Adjasi vd. (2008) EGARCH modeli ile döviz kuru volatilitesinin Gana pay piyasası volatilitesi üzerinde yarattığı etkileri incelemiş ve döviz kuru volatilitesi ile Gana pay piyasası volatilitesi arasında negatif ilişki olduğu tespit edilmiş ve ulusal paranın değer kaybetmesi durumunda pay piyasası getirilerinin yükseleceği belirtilmiştir. Mozumder, De Vita, Kyaw ve Larkin (2015) ise, döviz piyasaları ile pay piyasaları arasındaki volatilite yayılım etkilerini üç gelişmiş ülke (İrlanda, Hollanda ve İspanya) ve üç gelişmekte olan ülke (Brezilya, Güney Afrika ve Türkiye) için 3 Mart 2001-26 Aralık 2012 dönemi verileri üzerinden EGARCH modeli kullanarak incelemiş ve döviz piyasaları ile pay piyasaları arsında hem gelişmiş hem de gelişmekte olan ülkeler için kriz döneminde asimetrik volatilite yayılım etkisinin bulunduğunu tespit etmişlerdir. Benzer şekilde, Yamak, Kolcu ve Köyel (2018)'de döviz kuru volatilitesi ile borsa endeks volatilitesi arasındaki ilişkiyi incelemiştir. Yamak vd. (2018) çalışmalarında araştııılan etkinin asimetrik olup olmadığını BiST100 endeksi ve dolar kuruna ilişkin Ocak 2007-Mayıs 2017 dönemi verilerini kullanarak incelemiş ve pozitif döviz kuru volatilitesinden borsa endeks volatilitesine doğru tek yönlü nedensellik ilişkisinin bulunduğu, pozitif ve negatif borsa endeks volatilitesinden ise döviz kuru volatilitesine doğru herhangi bir nedensellik ilişkisinin bulunmadığına yönelik bulgular elde etmişlerdir.

O'Donnell ve Morales (2009), Çiçek (2010) ve Kang ve Yoon (2013) çalışmalarında ise döviz kuru volatilitesi ile pay getirisi volatilitesi arasında yayılım etkisinin bulunmadığına yönelik çeşitli bulgular elde edilmiştir. O’Donnell ve Morales (2009), Çek Cumhuriyeti, Macaristan, Polonya ve Slovakya pay ve döviz piyasalarının 1999-2006 dönemi verilerini kullanarak döviz piyasaları ile pay piyasaları arasındaki volatilite yayılım etkisini EGARCH modeli ile incelemiş ve ele alınan örneklem dönem itibariyle, gerek pay piyasalarından döviz piyasalarına doğru gerekse döviz piyasalarından pay piyasalarına doğru volatilite yayılım etkilerinin istatistiki olarak anlamlı olmadığı sonucuna ulaşmışlardır. Çiçek (2010) döviz kurları, pay piyasaları ve devlet iç borçlanma senetleri arasındaki volatilite yayılım etkisini çok değişkenli EGARCH modeli ile incelemiş ve devlet iç borçlanma senetleri ve pay piyasasından döviz kuru piyasasına doğru istatistiki olarak anlamlı bir fiyat yayılıma etkisinin bulunduğu, döviz kurundan diğer iki piyasaya doğru ise istatistiki olarak anlamlı bir fiyat yayılım etkisinin bulunmadığı yönünde bulgulara ulaşmıştır. Kang ve Yoon (2013) ise, çok değişkenli GJR-GARCH modelini kullanarak döviz kuru ile pay piyasası arasındaki volatilite yayılım etkisini Güney Kore piyasası için 8 Ocak 1990-28 Aralık 2009 dönemine ilişkin verileri üzerinden incelenmiş ve pay piyasasından döviz piyasasına doğru tek yönlü volatilite yayılım etkisinin olduğu, kriz öncesi dönem için iki piyasa arasında volatilite yayılım etkisinin olmadığı fakat kriz sonrası dönem için döviz piyasasından pay piyasasına doğru tek yönlü volatilite yayılım etkisi tespit edilmiştir. Çalışmada iki piyasa arasındaki volatilite yayılım etkilerinin asimetrik olmadığı belirtilmiştir.

Farklı ülkelerde farklı örneklemler ve farklı dönemler üzerinde gerçekleştirilen çalışmalardan Apte (2001), Bodart ve Reding (2001), Erdem vd. (2005), Beer ve Hebein (2008), Raghavan ve Dark (2008), Fedorova ve Saleem (2010), Okpara ve Odionye (2012), Akkaş ve Sayılgan (2016), Aktaş vd. (2018) çalışmalarında döviz kurlarından ve pay getirilerine doğru volatilite yayılım etkisini bulunduğuna yönelik önemli kanıtlar elde edilmiştir. 
Apte (2001), Hindistan pay piyasası ve döviz kurlarına ilişkin 1991-2000 dönemi verilerini kullanarak pay fiyatları ile nominal döviz kurları arasında volatilite yayılım etkisini EGACRH modeli ile incelemiş ve döviz piyasasından pay piyasasına doğru anlamlı volatilite yayılım etkisinin olduğuna yönelik bulgular elde etmiştir. Bodart ve Reding (2001), beş Avrupa ülkesindeki yedi farklı sektöre ilişkin 1990-1998 dönemi haftalık verilerini kullanarak döviz kuru oynaklıklarının sektörlerin pay senedi ortalama getirileri ve varyanslarına yaptığı etkileri incelemiş ve döviz kurlarından pay senedi getirilerine doğru volatilite yayılım etkisinin olduğu, fakat bu etkinin oldukça küçük olduğunu tespit etmişlerdir. Bodart ve Reding (2001) ayrıca, döviz kurlarından pay senedi getirilerine doğru tespit edilen volatilite yayılım etkisinin döviz kuru rejimlerinden ve döviz kurunda meydana gelen şokların büyüklük ve yönlerinden etkilendiğini belirtilmişlerdir. Erdem vd. (2005) ise, döviz kuru, faiz oranı, enflasyon, endüstriyel üretim ve para arzı ile BIST endeksleri arasındaki volatilite yayılım etkisini Ocak 1991-Ocak 2004 dönemi için EGARCH modeli kullanarak incelemiş ve enflasyon ve faiz oranından BiST endekslerine, para arzından BIST Mali endeksine, döviz kurundan da BIST 100 ve endüstriyel endekslere doğru güçlü volatilite yayılım etkilerinin bulunduğuna ilişkin bulgulara ulaşmışlardır.

Döviz piyasaları ile pay piyasaları arasındaki volatilite yayılım etkisini 1997-2004 dönemi için dört G-8 ülkesi olarak ABD, Kanada, Japonya ve Birleşik Krallık ve gelişmekte olan ülkeler olarak Hong-Kong, Singapur, Güney Kore, Hindistan ve Filipinler piyasaları üzerinden inceleyen Beer ve Hebein (2008) ise, ABD, Kanada, Japonya ve Hindistan için döviz kurlarından pay piyasalarına anlamlı pozitif volatilite yayılım etkisinin bulunduğu, gelişmiş ülkelerde hem pay hem de döviz piyasalarında volatilitenin sürekli etkilere sahip olmadığı, gelişmekte olan ülkeler için ise her iki piyasada da volatilitenin sürekli etkilere sahip olduğu tespit edilmiştir. Benzer bulgular elde edilen diğer bir çalışmada ise, Raghavan ve Dark (2008), VAR-GARCH modelini kullanarak USD/AUD döviz kuru ile Avustralya pay piyasasını temsil eden All Ordinaries Index (AOI) arasındaki volatilite yayılım etkisini incelemiş ve USD/AUD döviz kurundan pay piyasasına tek yönlü volatilite yayılımının olduğu tespit edilmiştir. Fedorova ve Saleem (2010) ise, gelişmekte olan Doğu Avrupa ülkelerine ilişkin Ocak 1995-Aralık 2008 dönemi verilerini kullanarak döviz piyasası ile pay piyasası arsındaki volatilite yayılım etkisini Multi-GARCH modellerden olan GARCH-BEKK modeli kullanarak incelemiş ve ülkelerin pay piyasaları ve döviz piyasaları arasında anlamlı getiri ve volatilite ilişkileri tespit etmişlerdir. Çalışmada tüm ülkeler için döviz piyasalarından pay piyasalarına doğru anlamlı volatilite yayılım etkilerinin bulunduğuna yönelik güçlü bulgular elde edilmiştir.

Nijerya'da döviz kuru ve pay fiyatları arasındaki volatilite yayılım etkisini inceleyen Okpara ve Odionye (2012), 1990-2009 dönemi verilerini EGARCH modeli ile analiz etmiş ve iki piyasa arasında uzun dönem denge ilişkisinin bulunmadığı, döviz kurundan pay piyasasına doğru tek yönlü güçlü volatilite yayılım etkisinin bulunduğunu tespit etmişlerdir. Akkaş ve Sayılgan (2016), BIST 100 endeksi ile USD/TRY kuru arasındaki volatilite yayılımını 2 Ocak 2002-31 Aralık 2015 dönemi günlük verilerini kullanarak VAR-BEKK-GARCH modeli aracılığıyla incelemiş ve iki piyasa arasında kriz dönemi hariç diğer dönemlerde çift yönlü oynaklık yayılım etkisi bulunduğuna yönelik, kriz döneminde ise, döviz piyasasından pay piyasasına doğru tek yönlü volatilite yayılım etkisinin bulunduğuna yönelik bulgular elde etmişlerdir. Aktaş, Kayalıdere ve Karataş Elçiçek (2018) ise, petrol ve döviz fiyat serilerinden BiST 100 endeksi getiri serisine doğru volatilite yayılımını 18 Eylül 201215 Eylül 2017 dönemi için EGARCH modeli kullanarak incelemiş ve döviz kurunda meydana gelen şokların BiST 100 endeks getirileri üzerinde negatif, petrol fiyatlarında meydana gelen şoklar ise pozitif etki yarattığına ve döviz kurundan BIST 100 endeksine doğru volatilite yayılım etkisinin pozitif olduğuna yönelik bulgulara ulaşmışlardır.

Literatürde döviz kuru oynaklığı ile turizm talebi ve turizm gelirleri gibi turizm sektörüne ilişkin önemli göstergeler arasındaki ilişkileri inceleyen çok sayıda çalışma bulunmaktadır. Söz konusu çalışmalardan bir kısmı döviz kuru oynaklıklarının turizm sektörü üzerinde önemli etkilerinin bulunduğunu tespit ederken, bir kısmı ise değişkenler arasında anlamlı ilişkilerin bulunmadığını tespit etmiştir. Döviz kuru oynaklığı ile turizm talebi, turist sayısı ya da turizm gelirleri gibi değişkenler arasındaki ilişkileri inceleyen Crouch (1994), Toh vd. (1997), íçöz vd. (1998), Webber (2001), Eilat ve Einav (2004), Dritsakis (2004), Patsouratis vd. (2005), Bahar (2007) ve Akar (2012) çalışmalarında döviz kuru oynaklıklarının turizm talebi ve turizm gelirlerini belirleyen önemli etkenlerden biri olduğu sonucuna varmışlardır. Crouch (1997), turizm talebinin tahmininde döviz kurunun etkisini incelemiş ve döviz kurunun turizm talebinin tahmininde önemli bir etken olduğunu vurgulamıştır. Bahar (2007) ise, devalüasyonun ve döviz kuru değişimlerinin turist sayılarındaki etkisini 
Türkiye için incelemiş ve döviz kurlarındaki artışlarla turist sayılarında da önemli ölçüde artış yaşandığı sonucuna ulaşmıştır. Öte yandan Akar (2012) Avrupa ülkeleri ve ABD'den Türkiye'ye olan turizm talebi ile döviz kurları arasındaki ilişkinin pozitif ve anlamlı olduğuna yönelik bulgular elde etmiş ve yabancı turistlerin kendi para birimlerinin değerli olduğu yerlere turistik seyahatler gerçekleştirme yöneliminde olduklarını belirtmiştir. Döviz kurundaki değişimler ile turizm gelirleri arasındaki nedensellik iliş̧isini inceleyen Narayan (2008) ise, iki değişken arasında ters yönlü bir nedensellik ilişkisinin bulunduğu sonucuna ulaşmıştır.

Konu ile ilgili farklı örneklemler üzerine gerçekleştirilen Eugenio-Martin ve Morales (2004), Mervar ve Payne (2007) ve Demirel vd. (2008) çalışmalarında ise, döviz kuru oynaklıklarının turist sayısı ve turizm gelirleri üzerinde anlamlı etkilerinin olmadığına yönelik bulgulara ulaşılmıştır. Demirel vd. (2008) Türkiye'ye yüksek sayıda turist gönderen ülkeler olan ABD, İngiltere, Almanya ve Fransa gibi ülkelerden gelen turistlerin turizm harcaması davranışları üzerinde döviz kuru değişimlerinin anlamlı bir etken olmadığını belirtmişlerdir. Çalışmada bunun nedeninin söz konusu ülkelerin göreceli gelir seviyesinin yüksek olması gösterilmiştir.

\section{Veri ve Metodoloji}

Bu çalışmada, literatürdeki çalışmalardan farklı olarak, döviz kuru volatilitesinin turizm talebi, turizm geliri veya turist sayısı üzerindeki etkilerinden ziyade turizm firmalarının pay getirisi volatiliteleri üzerindeki yayııım etkileri incelenerek literatüre katkı sağlanması amaçlanmıştır. Bu bağlamda, döviz kurları ile BiST Turizm Endeksi (XTRZM) getirileri arasındaki volatilite yayılım etkisi ekonometrik yöntemlerle belirlenmeye çalışılış̧tır. Çalışma amacı doğrultusunda, konvertibilitesi yüksek para birimleri olan USD, EUR, JPY ve GBP ve Türkiye'ye yüksek miktarda turist gönderen ülkelerden biri olan Rusya'nın para birimi olan RUB döviz kurları çalışma kapsamına alınmıştır. Yabancı turistler, turizm sektöründe faaliyet gösteren firmaların karlılıkları için büyük öneme sahiptirler. Özellikle tatil dönemlerinde Rusya, İngiltere ve Almanya gibi ülkelerde Türkiye'ye gelen yüksek miktarda yabancı turist turizm firmalarının karlılıklarında önemli rol oynamaktadırlar. Döviz kuru ve pay piyasası arasındaki ilişkiyi ifade eden yaklaşımlardan olan geleneksel yaklaşım turizm sektörü açısından düşünüldüğünde, yerli paranın değerinde meydana gelen düşüşlerin yabancı turistleri cezbedeceği ve yabancı turist sayısı ve turizm gelirlerinde artış meydana geleceği söylenebilir. Turizm firmalarının gelirlerinde meydana gelen değişimlerin pay fiyatlarına da yansıyacağı düşünüldüğünde, döviz kurlarındaki değişimlerin turizm firmalarının pay fiyatları üzerinde etkili olması beklenmektedir.

Tablo 1'de 2010-2019 yıllarında Türkiye'ye en fazla turist gönderen ilk beş ülke yer almaktadır.

Tablo 1. Türkiye'ye En Fazla Turist Gönderen Ülkeler (2010-2019)

\begin{tabular}{cccccc}
\hline Yıllar/Ülkeler & 1. Ülke & 2. Ülke & 3. Ülke & 4. Ülke & 5. Ülke \\
\hline 2010 & Almanya & Rusya Fed. & İngiltere & İran & Bulgaristan \\
& $(4.385 .263)$ & $(3.107 .043)$ & $(2.673 .605)$ & $(1.885 .097)$ & $(1.433 .970)$ \\
2011 & Almanya & Rusya Fed. & İngiltere & İran & Bulgaristan \\
& $(4.826 .315)$ & $(3.468 .214)$ & $(2.582 .054)$ & $(1.879 .304)$ & $(1.491 .561)$ \\
2012 & Almanya & Rusya Fed. & İngiltere & Bulgaristan & Gürcistan \\
& $(5.028 .745)$ & $(3.599 .925)$ & $(2.456 .519)$ & $(1.492 .073)$ & $(1.404 .882)$ \\
2013 & Almanya & Rusya Fed. & İngiltere & Gürcistan & Bulgaristan \\
& $(5.041 .323)$ & $(4.269 .306)$ & $(2.509 .357)$ & $(1.769 .447)$ & $(1.582 .912)$ \\
2014 & Almanya & Rusya Fed. & İngiltere & Gürcistan & Bulgaristan \\
& $(5.250 .036)$ & $(4.479 .049)$ & $(2.600 .360)$ & $(1.755 .289)$ & $(1.693 .591)$ \\
2015 & Almanya & Rusya Fed. & İngiltere & Gürcistan & Bulgaristan \\
& $(5.580 .792)$ & $(3.649 .003)$ & $(2.512 .139)$ & $(1.911 .832)$ & $(1.821 .480)$ \\
2016 & Almanya & Gürcistan & İngiltere & Bulgaristan & İran \\
& $(3.890 .074)$ & $(2.206 .266)$ & $(1.711 .481)$ & $(1.690 .766)$ & $(1.665 .160)$ \\
2017 & Rusya Fed. & Almanya & İran & Gürcistan & Bulgaristan \\
& $(4.715 .438)$ & $(3.584 .653)$ & $(2.501 .948)$ & $(2.438 .730$ & $(1.852 .867)$ \\
2018 & Rusya Fed. & Almanya & Bulgaristan & İngiltere & Gürcistan \\
& (5.964.613) & $(4.512 .360)$ & $(2.386 .885)$ & $(2.254 .871)$ & $(2.069 .392)$ \\
2019 (Eylül) & Rusya Fed. & Almanya & İngiltere & Bulgaristan & İran \\
& (5.902.774) & $(4.009 .337)$ & $(2.198 .150)$ & $(1.995 .894)$ & $(1.640 .028)$ \\
\hline
\end{tabular}

Not: Parantez içindeki değerler ilgili ülkeden ilgili yılda Türkiye'ye giriş yapan turist sayısını ifade etmektedir.

Kaynak: TÜiK Turizm sınır istatistikleri ve Turizm ve Kültür Bakanlığı yıllık sınır istatistiklerinden derlenmiştir. 
Tablo 1'e göre, 2010-2016 yıllarında Almanya, 2017-2019 yıllarında ise Rusya Türkiye'ye en fazla turist gönderen ülke konumundadır. İngiltere ise 2017 ve 2018 yılları dışındaki dönemlerde Türkiye'ye en fazla turist gönderen üçüncü ülke konumundadır.

Çalışmada oluşturulan veri setlerinde veri miktarını en fazla elde edebilmek amacıyla döviz kurları ve turizm endeksinin ulaşılabilen tüm verileri kullanılmıştır. Bu bağlamda, veriler XTRZM endeksinin işleme başladığı tarih olan 27 Aralık 1996' dan itibaren toplanmış ve analizlere uygun hale getirilmiştir. Tablo 2'de de görüleceği üzere USD, JPY ve GBP döviz kurlarına ilişkin veriler 6 Ocak 1997-11 Haziran 2019 dönemini, EUR döviz kuruna ilişkin veriler Euro para biriminin kullanılmaya başlanmasından itibaren 4 Ocak 1999-11 Haziran 2019 dönemini, RUB döviz kuruna ilişkin veriler ise, ruble para birimine ilişkin verilere ulaşılabilen tarihler olan 14 Nisan 2010-11 Haziran 2019 dönemini kapsamaktadır.

Tablo 2. Araştırmaya Dahil Edilen Döviz Kurları ve Dönemleri

\begin{tabular}{lcc}
\hline Döviz Kuru & Kod & Dönem \\
\hline Amerikan doları & USD & 06.01.1997- 11.06.2019 (5607 Gün Veri) \\
Euro & EUR & 04.01.1999- 11.06.2019 (5109 Gün Veri) \\
Japon yeni & JPY & 06.01.1997- 11.06.2019 (5607 Gün Veri) \\
İngiliz poundu & GBP & 06.01.1997- 11.06.2019 (5607 Gün Veri) \\
Rus rublesi & RUB & $12.04 .2010-11.06 .2019$ (2034 Gün Veri) \\
\hline
\end{tabular}

Çalışmada kullanılan XTRZM endeksine ilişkin veriler FiNNET (Financial Information News Network) veri tabanından, döviz kurlarına ilişkin veriler ise TCMB (Türkiye Cumhuriyet Merkez Bankası)'nın web sayfasından sağlanmıştır. Endeks ve döviz kurlarına ilişkin getiriler, kapanış fiyat serileri kullanılarak aşağıda yer alan sürekli getiri formülü yardımıyla hesaplanmıştır.

$$
R_{t}=\operatorname{Ln}\left(\frac{P_{t}}{P_{t-1}}\right)
$$

Denklem 1'de $R_{t}$ endeks ve döviz serilerinin $t$ günündeki getirisini, $P_{t}$ endeks ve döviz serilerinin $t$ günündeki kapanış fiyatını, $\mathrm{P}_{\mathrm{t}-1}$ ise serilerin $\mathrm{t}-1$ günündeki kapanış fiyatını ifade etmektedir. Çalışmada döviz kurları ile turizm endeksi getirileri arasındaki volatilite yayılım etkisi incelenmeden önce serilerde mevsimsel veya konjonktürel etkilerin varlığı grafikler yardımıyla incelenmiştir. Şekil 1'de yer alan endeks ve döviz fiyat grafikleri incelendiğinde tüm serilerde mevsimsel ya da konjonktürel dalgalanmaların bulunduğu görülmektedir. Serilere ilişkin getiri grafikleri incelendiğinde çok sayıda uç noktaların (outlier) bulunduğu gözlemlenmektedir. Serilerde gözlemlenen mevsimsel dalgalanmalar ve uç noktalar öngörümlemede sapmalara neden olabilmektedir (Özmen ve Poyraz, 1999: 167). Bu nedenle, hareketli ortalamalara oranlama yöntemi kullanılarak seriler mevsimsel ve konjonktürel dalgalanmalardan ve uç noktalardan arındırılarak söz konusu olguların öngörümleme üzerinde yaratacağı olası etkiler minimuma indirilmeye çalışılmıştır.

Pay senedi fiyatları, döviz kuru, enflasyon oranları, faiz oranları gibi birçok değişkende gözlenen volatilite ARCH/GARCH ve türevi modeller ile tahmin edilebilmektedir. Birden fazla değişken olması ise değişkenlerin sahip olduğu ortak oynaklık yapısının ölçülmesi için Multivariate GARCH (MGARCH) modelleri kullanılmaktadır (Erdoğan ve Bozkurt, 2009: 145). Bu nedenle çalışmada döviz kurları ile turizm endeksi getirileri arasındaki volatilite yayılımı bir MGARCH modeli olan Diagonal VECH GARCH modeli ile incelenmiştir. Bollersev, Engle ve Wooldridge (1988) tarafından önerilen Diagonal VECH GARCH modeli, tek değişkenli ARCH-GARCH modellerin, $n$ sayıda değişkenden oluşan bir yapı içerisinde tahmin edilmesine, birden fazla değişken arasındaki koşullu kovaryans ve koşullu korelasyon gibi faktörlerin incelenmesine imkân veren bir model olmasından dolayı tercih edilmiştir.

Diagonal VECH GARCH modelinde koşullu varyans, $A_{j}$ ve $G_{j}(N \times(N+1) / 2) \times(N \times(N+1) / 2)$ boyutundaki parametre matrisleri olmak üzere denklem 2'deki gibi ifade edilmektedir; 


$$
\operatorname{vech}\left(H_{t}\right)=c+\sum_{j=1}^{q} A_{j} \operatorname{vech}\left(\varepsilon_{t-j} \varepsilon^{\prime}{ }_{t-j}\right)+\sum_{j=1}^{p} G_{j} \operatorname{vech}\left(H_{t-1}\right)
$$

Denklem 2'de c sabit terim, vech(...) NxN boyutlu simetrik matrisin alt üçgensel bölgede kalan kısmını $\mathrm{Nx}(\mathrm{N}+1) / 2) \times 1$ boyutlu bir vektöre çeviren operatörü, $\mathrm{H}_{t}$ matrisi ise, $\mathrm{NxN}$ boyutlu pozitif tanımlı bir matrisi ifade etmektedir. Diagonal VECH GARCH modelinde değişkenlere ilişkin koşullu varyanslar, kendi geçmiş dönem değerlerine ve kendi geçmiş dönem hata terimlerinin karelerine, koşullu kovaryanslar ise, kendi geçmiş dönem değerlerine ve kendi geçmiş dönem hatalarının çarpımlarına bağlı olarak hesaplanmaktadır (Erdoğan ve Bozkurt, 2009:147; Songül, 2010 :23). iki değişkenli bir Diagonal VECH GARCH(1,1) modeli matris formunda;

$$
h_{t}=\left[\begin{array}{l}
h_{11, t} \\
h_{12, t} \\
h_{22, t}
\end{array}\right]=\left[\begin{array}{c}
c_{01} \\
c_{02} \\
c_{03}
\end{array}\right]+\left[\begin{array}{ccc}
a_{11} & 0 & 0 \\
0 & a_{22} & 0 \\
0 & 0 & a_{33}
\end{array}\right]\left[\begin{array}{c}
\varepsilon_{1, t-1}^{2} \\
\varepsilon_{1, t-1} \varepsilon_{2, t-1} \\
\varepsilon_{2, t-1}^{2}
\end{array}\right]+\left[\begin{array}{ccc}
g_{11} & 0 & 0 \\
0 & g_{22} & 0 \\
0 & 0 & g_{33}
\end{array}\right]\left[\begin{array}{l}
h_{11, t-1} \\
h_{12, t-1} \\
h_{22, t-1}
\end{array}\right]
$$

ya da,

$$
\begin{aligned}
& h_{11, t}=c_{01}+a_{11} \varepsilon_{1, t-1}^{2}+g_{11} h_{11, t-1} \\
& h_{12, t}=c_{02}+a_{22} \varepsilon_{1, t-1} \varepsilon_{2, t-1}+g_{22} h_{12, t-1} \\
& h_{22, t}=c_{03}+a_{33} \varepsilon_{2, t-1}^{2}+g_{33} h_{22, t-1}
\end{aligned}
$$

şeklinde gösterilebilir (Engle ve Kroner, 1995: 126).

Çalışmada döviz kurları ile BIST XTRZM endeksi getirileri arasındaki volatilite yayılım etkileri her döviz kuru için farklı bir model kurularak incelenmiştir. Bu bağlamda, model 1 USD, model 2 EUR, model 3 JPY, model 4 GBP ve model 5 RUB döviz kurlarından XTRZM endeksi getirilerine olan volatilite yayılım etkilerini ifade eden modeller olarak oluşturulmuşlardır. Döviz kurları ile turizm endeksi getirileri arasındaki volatilite yayılım etkisi Diagonal VECH GARCH modeli ile incelenmeden önce değişkenlere ilişkin tanımlayıcı istatistikler hesaplanmış ve serilerin birim kök içerip içermedikleri Dickey ve Fuller (1979) tarafından geliştirilen Augmented Dickey-Fuller (ADF) birim kök testi, Phillips ve Perron (1988) tarafından geliştirilen Phillips-Perron (PP) birim kök testi ve Kwiatkowski, Phillips, Schmidt ve Shin (1992) tarafından geliştirilen KPSS birim kök testi ve serilere ilişkin grafikler yardımıyla incelenmiştir. Hata terimlerinin GARCH tipi modellemeye uygun olup olmadığı ise ARCH testi ile serisel korelasyon durumu ise hata terimleri korelogramları ile incelenmiştir. Sonrasında değişkenler arasındaki volatilite yayılım etkileri Diagonal VECH GARCH modeli kullanılarak incelenmiştir. Ardından değişkenlerin bireysel koşullu varyansları ve birlikte geçekleştirdikleri koşullu kovaryansları grafik şeklinde verilmiştir. Son olarak, oluşturulan modellerin hata terimlerinde otokorelasyon ve değişen varyansın varlığı Ljun-Box (1978) $Q$ ve $Q^{2}$ istatistikleri incelenmiş ve model spesifikasyonunun doğruluğu sınanmıştır.

\section{Bulgular}

Çalışma kapsamında ele alınan döviz kurları ve BIST XTRZM endeksi getiri serilerine ilişkin ortalama, medyan, maksimum ve minimum değerler, standart sapma, çarpıklık ve basıklık katsayıları ve Jargue-Bera istatistikleri Tablo 3'te, serilerin fiyat ve getiri grafikleri ise Şekil 1'de yer almaktadır.

Tablo 3 incelendiğinde, döviz kuru getiri serilerinin ortalamasının beş modelde de turizm endeksi getiri serisi ortalamasından yüksek olduğu ve medyanın daha yüksek değerler aldığı görülmektedir. Model 5 dışındaki tüm modellerde döviz kuru getiri serilerinin maksimum ve minimum değerleri arasındaki farklar turizm endeksi getiri serilerinin maksimum ve minimum değerleri arasındaki farklardan daha fazladır. Her beş modelde de turizm endeksi getirilerinin standart sapmalarının döviz kuru getiri serilerinin standart 
sapmalarından daha yüksek olduğu görülmektedir. Çarpıklık katsayıları incelendiğinde, Model 5'te yer alan serilerin negatif katsayılara, dolayısıyla sola çarpık dağılımlara, diğer modellerde yer alan serilerin ise pozitif katsayılara ve dolayısıyla sağa çarpık dağılımlara sahip olduğu görülmektedir. Basıklık değerleri incelendiğinde ise, tüm modellerde yer alan serilerin pozitif katsayılara, dolayısıyla sivri dağılımlara sahip oldukları görülmektedir.

Tablo 3. Değişkenlere Iliş̧kin Tanımlayıcı İstatistikler

\begin{tabular}{|c|c|c|c|c|c|c|}
\hline & \multicolumn{2}{|c|}{ Model 1} & \multicolumn{2}{|c|}{ Model 2} & \multicolumn{2}{|c|}{ Model 3} \\
\hline & RXTRZM & RUSD & RXTRZM & REUR & RXTRZM & RJPY \\
\hline Ortalama & 0,030882 & 0,071096 & 0,032234 & 0,056481 & 0,030882 & 0,072243 \\
\hline Medyan & 0,000000 & 0,028329 & $-0,002819$ & 0,000000 & 0,000000 & 0,000000 \\
\hline Maksimum & 19,84289 & 33,47320 & 19,84289 & 32,45127 & 19,84289 & 33,87835 \\
\hline Minimum & $-19,49537$ & $-12,5636$ & $-19,49537$ & $-12,26620$ & $-19,49537$ & $-17,46165$ \\
\hline Standart Sap. & 3,018741 & 1,041304 & 2,886820 & 1,084449 & 3,018741 & 1,273866 \\
\hline Çarpıklık & 0,146107 & 6,632627 & 0,301598 & 6,058848 & 0,146107 & 3,625947 \\
\hline Basıklık & 9,885234 & 214,9333 & 10,85627 & 175,4955 & 9,885234 & 108,0681 \\
\hline Jarque-Bera & 11095,28 & 10534545 & 13216,30 & 6365292 & 11095,28 & 2591346, \\
\hline Olasılık & 0,000000 & 0,000000 & 0,000000 & 0,000000 & 0,000000 & 0,000000 \\
\hline Sum & 173,1576 & 398,6356 & 164,6846 & 288,5594 & 173,1576 & 405,0660 \\
\hline Sum Sq. Dev. & 51086,33 & 6078,660 & 42568,68 & 6007,157 & 51086,33 & 9097,048 \\
\hline \multirow[t]{3}{*}{ Gözlem Sayısı } & 5607 & 5607 & 5109 & 5109 & 5607 & 5607 \\
\hline & \multicolumn{2}{|c|}{ Model 4} & \multicolumn{2}{|c|}{ Model 5} & & \\
\hline & RXTRZM & RGBP & RXTRZM & RRUB & & \\
\hline Ortalama & 0,030882 & 0,065900 & $-0,018055$ & 0,024909 & & \\
\hline Medyan & 0,000000 & 0,037259 & 0,007503 & 0,032507 & & \\
\hline Maksimum & 19,84289 & 33,49412 & 8,992616 & 12,86798 & & \\
\hline Minimum & $-19,49537$ & $-12,69494$ & $-14,72453$ & $-13,70272$ & & \\
\hline Standart Sap. & 3,018741 & 1,044535 & 1,788897 & 1,077699 & & \\
\hline Çarpıklık & 0,146107 & 6,659217 & $-0,738538$ & $-0,043906$ & & \\
\hline Basıklık & 9,885234 & 209,4179 & 10,01747 & 30,33484 & & \\
\hline Jarque-Bera & 11095,28 & 9995818 & 4936,958 & 71731,32 & & \\
\hline Olasılık & 0,000000 & 0,000000 & 0,000000 & 0,000000 & & \\
\hline Sum & 173,1576 & 369,5030 & $-41,59938$ & 57,39070 & & \\
\hline Sum Sq. Dev. & 51086,33 & 6116,440 & 7369,953 & 2674,785 & & \\
\hline Gözlem Sayısı & 5607 & 5607 & 2304 & 2304 & & \\
\hline
\end{tabular}

Değişkenlere ilişkin ortalama ve medyan değerlerinin çakışık olmaması ve çarpıklık ve basıklık değerlerinin 0'a eşit olmaması değişkenlerin normal dağılıma uyum sağlamadıklarına işaret etmektedir (Çil Yavuz, 2015: 34-37). Jargue-Bera istatistikleri ve olasılık değerleri incelendiğinde, beş modelde de hem turizm endeksi getiri serileri hem de döviz kuru getiri serilerinin yüksek istatistik değerlerine ve 0.05 'ten düşük olasılık değerlerine sahip oldukları ve değişkenlerin hiçbirinin normal dağılıma uyum sağlamadığı görülmektedir. Finansal verilerin genel olarak normal dağılım varsayımına uygun hareket etmedikleri doğrultusunda serilere ilişkin birim kök, değişen varyans, otokorelasyon ve seriler arasındaki volatilite yayılımı analizleri gerçekleştirilirken Schwarz Bayesyan Bilgi Kriteri (SBIC) esas alınmıştır. 


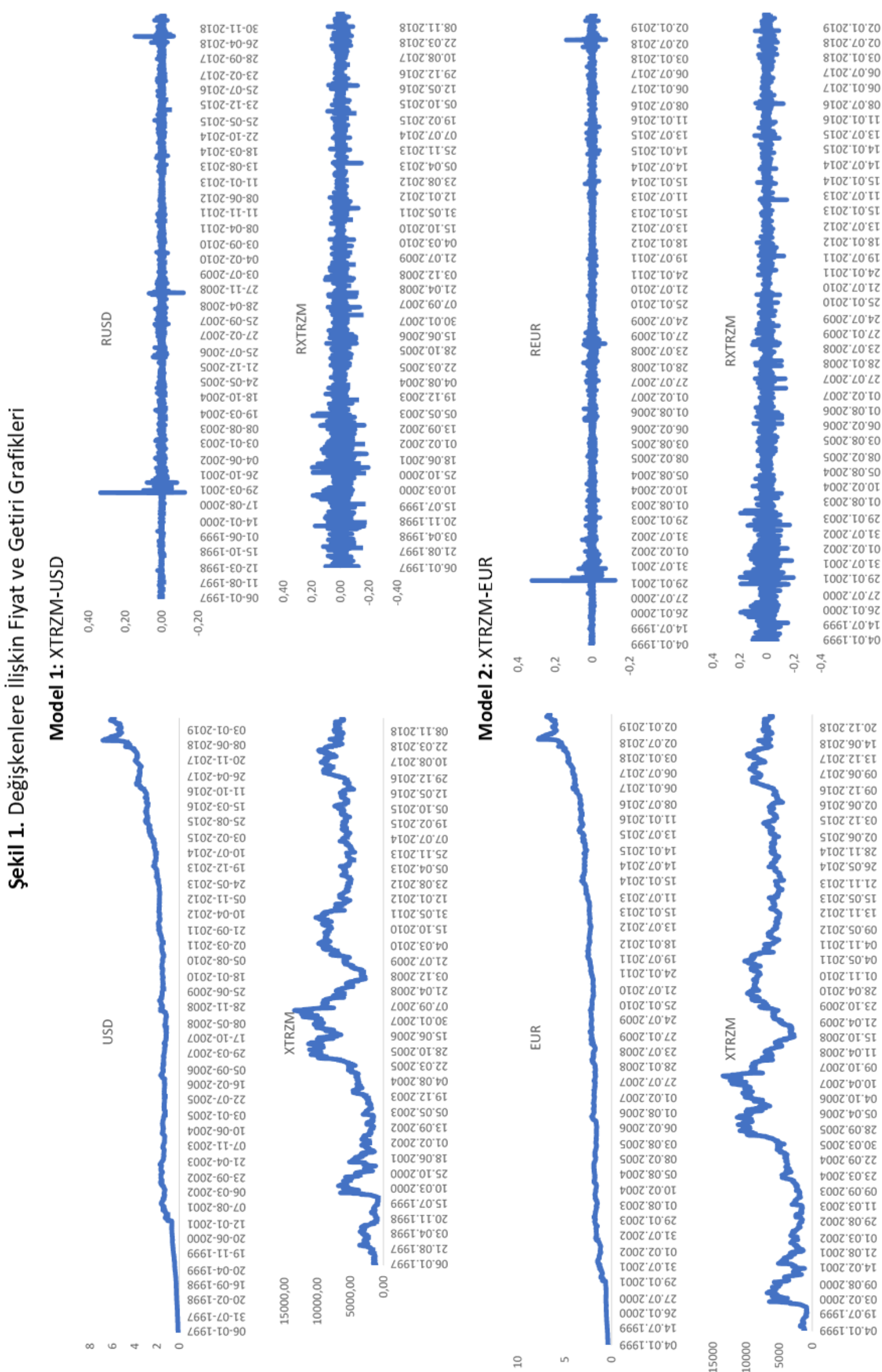



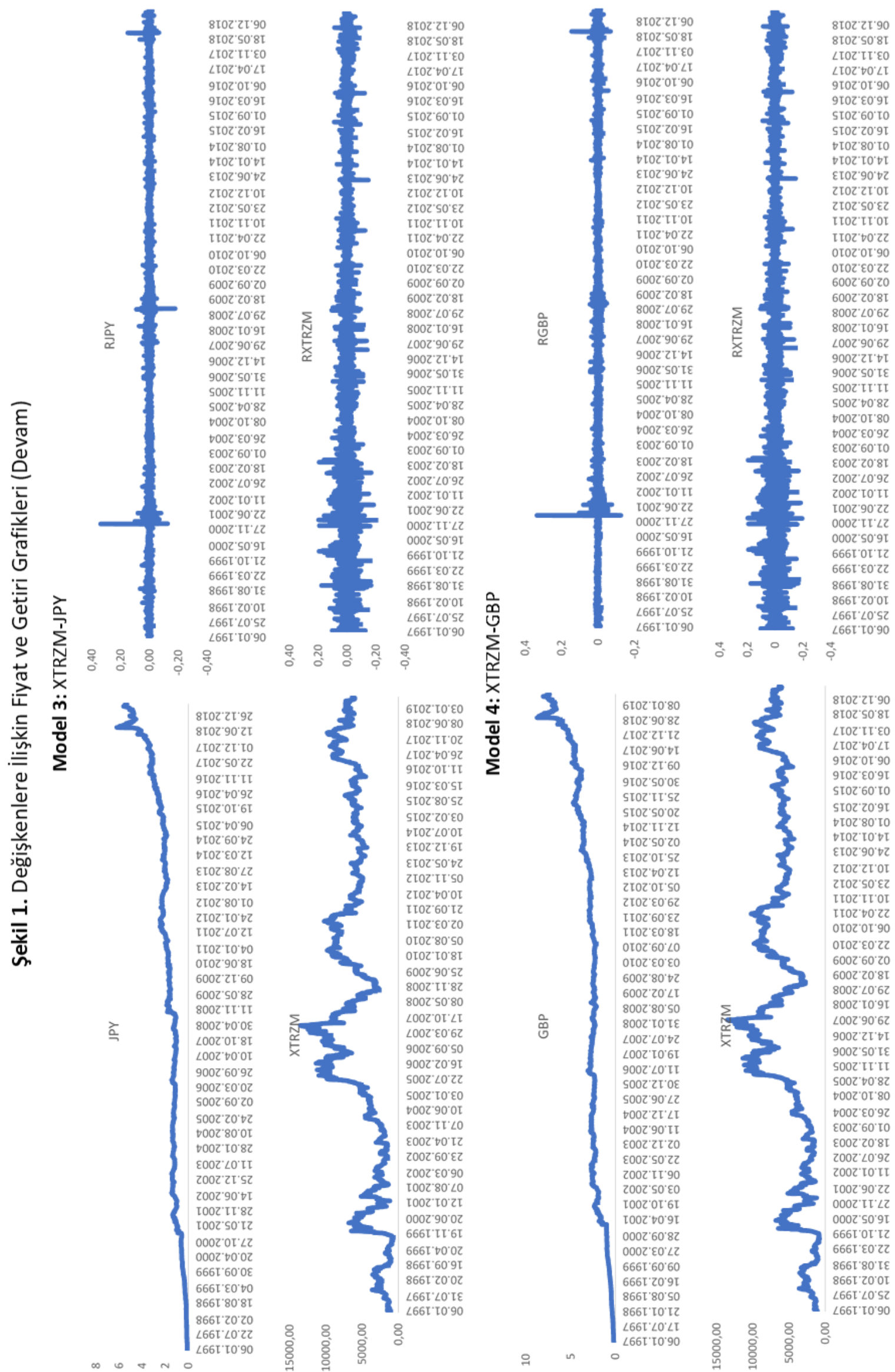


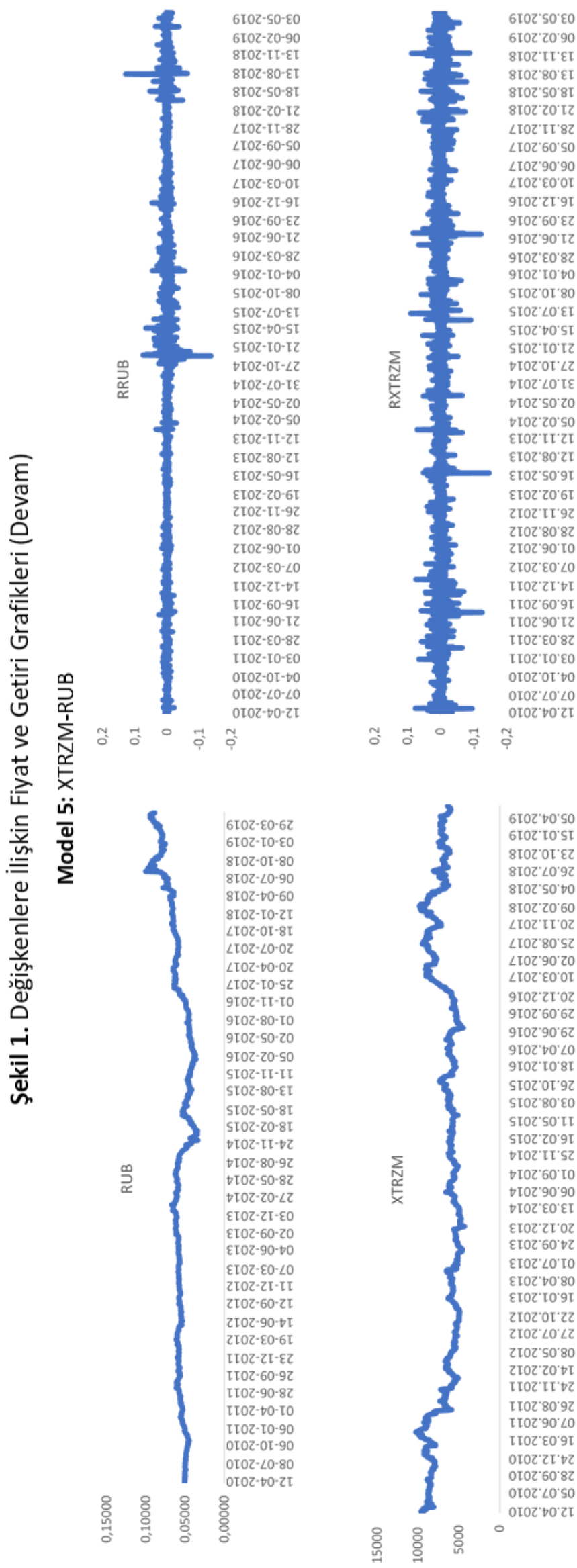


Şekil 1 incelendiğinde, RUB dışındaki döviz kuru fiyat serilerinde oldukça benzer ve yükselen bir trend olduğu görülmektedir. Modellerde farklı zaman boyutları ile yer alan turizm endeksi fiyat serileri ise dalgalı bir seyir izlemektedir. Genel olarak hem döviz hem de turizm endeksi fiyat serilerinde ortalamanın sabit olmadığı ve serilerin durağan yapıda olmadıkları söylenebilir. Serilere ilişkin getiri serisi grafikleri incelendiğinde gerek döviz kuru gerekse turizm endeksi getiri serilerinin ortalama bir değer etrafında dalgalanma davranışı sergilediği, diğer bir ifadeyle şoklardan sonra ortalamaya geri dönüş özelliği gösterdiği söylenebilir. Bu durumda, serilerde durağanlığın sağlandığı sezgisel olarak söylenebilir. Grafikler incelendiğinde özellikle döviz kurlarına ilişkin getiri serilerinde çeşitli dönemlerde volatilite kümelenmelerinin gerçekleştiğini görmek mümkündür. Grafikler incelendiğinde Model 1, 2, 3 ve 4'te döviz kuru getiri serilerinde 2001 yılının ilk 6 aylık dönemi, 2008 yılının son 2 ve 2009 yılının ilk 3 aylık dönemlerinde volatilite kümelenmeleri gözlenmektedir. Model 5'te yer alan RUB döviz kuruna ilişkin getiri serisinde ise diğer döviz kurlarından farklı olarak 2015 yıının ilk 6 aylık döneminde volatilite kümelenmesi gerçekleşmiştir. Son olarak ele alınan tüm döviz kurlarında 2018 yılının son 5 aylık döneminde volatilite kümelenmelerinin gerçekleştiği görülmektedir. Söz konusu volatilite kümelenmelerinin 2001 yılında Türkiye'nin iç dinamiklerinden kaynaklı yaşanan ekonomik kriz, 2008 küresel finansal kriz ve 2018 yılında yaşanan döviz kuru krizinden kaynaklandığı düşünülmektedir. Model 5'te ise, 2015 yılına denk gelen dönemde gerçekleşen volatilite kümelenmesinin ise, aynı yılda Türkiye ile Rusya arasında yaşanan siyasi sorunlardan kaynaklandığı düşünülmektedir. Modellerde yer alan turizm endeksi getiri serilerinde de döviz kuru getiri serilerine benzer dönemlerde volatilite kümelenmelerinin gerçekleştiğini söylemek mümkündür. Serilerde volatilite kümelenmelerinin gözlemlenmesi, serilerdeki gerçekleşen yüksek değişimleri, yüksek değişimlerin, düşük değişimleri ise düşük değişmelerin izlemesi anlamına gelmektedir. Grafik incelemeleri sonucu varılan, getiri serilerinde durağanlık ve volatilite kümelenmeleri yargıları sezgisel yargılar olup ekonometrik olarak test edilmeleri gerekmektedir. Serilerde durağanlık sınaması ADF, PP ve KPSS birim kök testleri ile gerçekleştirilmiştir. ADF, PP ve KPSS birim kök testlerine ilişkin sonuçlar Tablo 4'te yer almaktadır.

Tablo 4'te yer alan birim kök testlerine ilişkin sonuçlar incelendiğinde, her beş model için de hem döviz kuru getiri serileri hem de turizm endeksi getiri serilerinin, ADF ve PP test olasılık değerlerinin sabitsiz ve trendsiz, sabitli ve sabitli ve trendli birim kök modellerinde \%1 anlamlılık düzeyinde düzeyde durağan oldukları tespit edilmiştir. Serilerde durağanlığı ADF ve PP birim kök testlerinden farklı bir hipotezle test eden KPSS birim kök testi sonuçları incelendiğinde ise, tüm serilerin hem sabitli hem de sabitli ve trendli birim kök modellerinde olasılık değerlerinin 0,01 'den yüksek olduğu, dolayısıyla serilerin durağan olduğu tespit edilmiştir. Bu bağlamda KPSS birim kök testinin ADF ve PP birim kök testlerini destekler nitelikte sonuçlar verdiği söylenebilir. Model 1, 2, 3 ve 4'te RXTRZM serisine ilişkin sabitli ve Model 5'te RXTRZM serisine ilişkin sabitli ve trendli birim kök modeli olasılık değerinin 0,10'dan düşük olması ve Model 1, 2, 3 ve 4'te RXTRZM serisine ilişkin sabitli ve trendli birim kök modeli olasılık değerinin 0,05'ten düşük olması serilerde birim kök bulunduğuna yönelik şüpheler doğurmasına karşın tatmin edici kanıtlar sunmamaktadır. ADF, PP ve KPSS birim kök testleri sonuçları ve serilere ilişkin getiri grafikleri birlikte değerlendirildiğinde serilerin durağan olduğuna karar verilmiştir.

Volatilite analizlerinde serilerde hata teriminin koşullu değişen varyansa (heteroskedastisite) sahip olması durumunda serinin volatilitesinin $A R C H / G A R C H$ türevi modellerle incelemeye uygun olduğu söylenebilir (Topaloğlu, 2020: 25-26). Serilerin ARCH/GARCH tipi modellemeye uygun olup olmadıkları, diğer bir ifadeyle serilerde ARCH etkisinin bulunup bulunmadığı ARCH-LM testi ile sınanmıştır. Serilerde otokorelasyon olup olmadığı ise serilerin hata terimleri korelogramları ile sınanmıştır. ARCH-LM testi ve hata korelogramları testi sonuçları Tablo 5 'te yer almaktadır. 


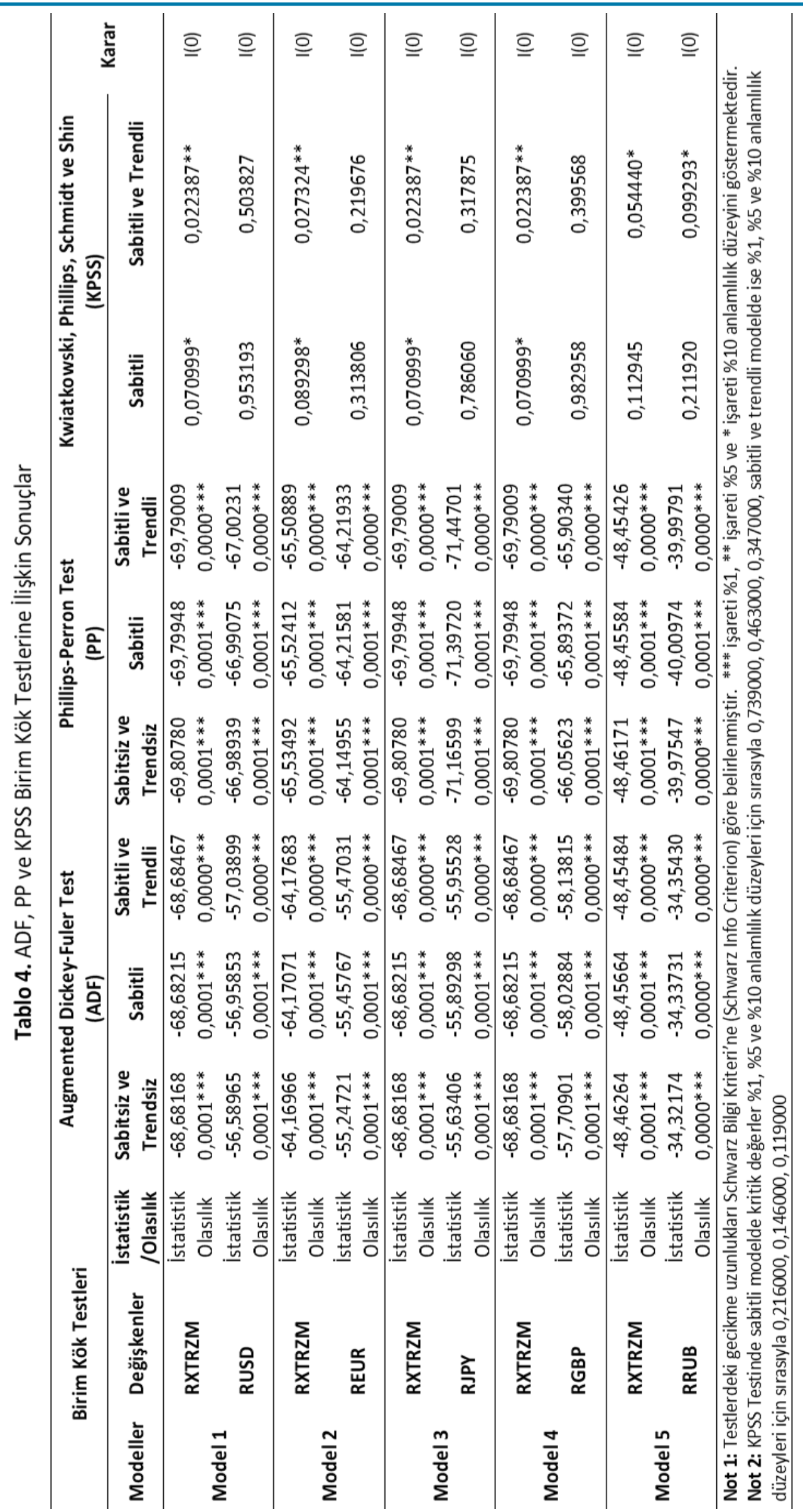


Tablo 5. Serilere Illişkin Değişen Varyans ve Otokorelasyon Test Sonuçları

\begin{tabular}{|c|c|c|c|c|c|}
\hline \multicolumn{6}{|c|}{ ARCH-LM Testi } \\
\hline Modeller & Değişkenler & F İstatistiği & F İstatistiği Olasılık & Gözlenen $\mathbf{R}^{\mathbf{2}}$ & $\mathbf{R}^{2}$ Olasılık \\
\hline \multirow{2}{*}{ Model 1} & RXTRZM & 316,657 & $0,0000^{* * *}$ & 335,186 & $0,0000 * * *$ \\
\hline & RUSD & 552,9928 & $0,0000 * * *$ & 496,3158 & $0,0000 * * *$ \\
\hline \multirow{2}{*}{ Model 2} & RXTRZM & 474,9414 & $0,0000 * * *$ & 432,5998 & $0,0000 * * *$ \\
\hline & REUR & 975,4505 & $0,0000 * * *$ & 811,9727 & $0,0000 * * *$ \\
\hline \multirow{2}{*}{ Model 3} & RXTRZM & 316,657 & $0,0000 * * *$ & 335,186 & $0,0000 * * *$ \\
\hline & RJPY & 587,8543 & $0,0000 * * *$ & 532,4796 & $0,0000 * * *$ \\
\hline \multirow{2}{*}{ Model 4} & RXTRZM & 316,657 & $0,0000 * * *$ & 335,186 & $0,0000 * * *$ \\
\hline & RGBP & 631,3579 & $0,0000 * * *$ & 587,3549 & $0,0000 * * *$ \\
\hline \multirow{2}{*}{ Model 5} & RXTRZM & 517,3496 & $0,0000 * * *$ & 475,4521 & $0,0000 * * *$ \\
\hline & RRUB & 345,1202 & $0,0000 * * *$ & 312,5476 & $0,0000 * * *$ \\
\hline \multicolumn{6}{|c|}{ Hata Terimleri Korelogramları } \\
\hline Modeller & Değişkenler & $\mathrm{AC}$ & PAC & Q-İstatistiği & Olasılık \\
\hline \multirow{2}{*}{ Model 1} & RXTRZM & 0,045 & 0,043 & 22,561 & $0,007 * * *$ \\
\hline & RUSD & 0,050 & 0,050 & 24,312 & $0,004 * * *$ \\
\hline \multirow{2}{*}{ Model 2} & RXTRZM & 0,041 & 0,040 & 16,648 & $0,055^{* *}$ \\
\hline & REUR & 0,056 & 0,056 & 15,383 & $0,000 * * *$ \\
\hline \multirow{2}{*}{ Model 3} & RXTRZM & 0,045 & 0,043 & 22,561 & $0,0078 * * *$ \\
\hline & RJPY & 0,022 & 0,024 & 34,035 & $0,000 * * *$ \\
\hline \multirow{2}{*}{ Model 4} & RXTRZM & 0,045 & 0,043 & 22,561 & $0,0078 * * *$ \\
\hline & RGBP & 0,009 & 0,010 & 42,613 & $0,002 * * *$ \\
\hline \multirow{2}{*}{ Model 5} & RXTRZM & 0,047 & 0,048 & 148,54 & $0,000 * * *$ \\
\hline & RRUB & 0,066 & 0,066 & 39,536 & $0,000 * * *$ \\
\hline
\end{tabular}

Not: Testlerdeki gecikme uzunlukları Schwarz Bilgi Kriteri'ne (Schwarz Info Criterion) göre belirlenmiştir. ***

işareti \%1, ** işareti $\% 5$ ve * işareti $\% 10$ anlamlılık düzeyini göstermektedir.

Tablo 5'te yer alan ARCH-LM ve hata terimi korelogramları sonuçlarına göre tüm serilerde hem değişen varyans hem de otokorelasyon sorunları bulunmaktadır. ARCH-LM test sonuçlarının anlamlı çıkması serilerde $A R C H$ etkisinin bulunduğuna işaret etmektedir. Bu durumda, serilerin ARCH/GARCH tipi modellemelere uygun oldukları söylenebilir. Çalışmada döviz kurları ile turizm endeks getirileri arasındaki volatilite yayılım etkileri Diagonal VECH GARCH modeli ile analiz edilmiştir. Modellere ilişkin Diagonal VECH GARCH analizi sonuçları Tablo $6^{\prime} \mathrm{da}$, model sonuçları doğrultusunda oluşturulan bireysel varyans ve ortak kovaryans grafikleri ise Şekil 2'de yer almaktadır.

Diagonal VECH GARCH modelinden elde edilen sonuçların yorumlanabilmesi için bazı kısıtlar mevcuttur. Modelde durağan bir yapı elde edebilmek için alfa ve beta katsayılarının toplamının 1'den küçük olması $(\alpha+\beta<1)$ ve kovaryans matrisinin pozitif belirli elde edilebilmesi için ortalama $(M)$, alfa ve beta katsayılarının anlamlı ve pozitif olması (mean $>0, \alpha>0$ ve $\beta>0$ ) gerekmektedir (Erdoğan ve Bozkurt, 2009: 156; Topaloğlu, 2020: 33). Diagonal VECH GARCH modelinde her bir değişken için ARCH ve GARCH parametreleri hesaplanmaktadır. Hesaplanan ARCH parametreleri şokun şiddetini, GARCH parametreleri ise şokun kalıcılığını göstermektedir. Genel anlamda ARCH modelleri koşullu varyansların türetilmesinde sınırlı sayıda gecikmeyi içermesi itibariyle kısa hafıza, GARCH modelleri ise hata karelerinin geçmiş değerlerine ek olarak, koşullu varyansın kendi geçmiş değerlerini içererek bu etkiyi ortaya çıkaracak tüm gecikmelere izin vermesi itibariyle uzun hafıza özelliği taşımaktadır (Çil Yavuz, 2015: 455). Modelde değişkenler arasındaki volatilite yayılım etkisi, etkinin şiddeti ve kalıcılığının ölçülmesi için ise, değişkenlerin ortak ARCH ve GARCH parametreleri hesaplanmaktadır. 
Tablo 6. Diagonal VECH GARCH Analiz Sonuçları

\begin{tabular}{|c|c|c|c|c|c|}
\hline \multirow{3}{*}{ Modeller } & \multirow{3}{*}{ Diagonal VECH } & \multicolumn{4}{|c|}{ Dönüştürülmüş Varyans Katsayıları } \\
\hline & & \multicolumn{4}{|c|}{ GARCH = M + A1. ${ }^{*}$ RESID(-1)*RESID(-1)' + B1. * GARCH(-1) } \\
\hline & & Katsayı & Std. Hata & z-İstatistiği & Olasılık \\
\hline \multirow{7}{*}{ Model 1} & M & 0,148772 & 0,003133 & 47,49184 & $0,0000 * * *$ \\
\hline & ARCH(XTRZM, XTRZM) & 0,823333 & 0,022669 & 36,32009 & $0,0000 * * *$ \\
\hline & $\mathrm{ARCH}(\mathrm{XTRZM}, \mathrm{USD})$ & 0,777621 & 0,024548 & 31,67745 & $0,0000 * * *$ \\
\hline & $\mathrm{ARCH}(\mathrm{USD}, \mathrm{USD})$ & 0,734447 & 0,027165 & 27,03691 & $0,0000 * * *$ \\
\hline & GARCH(XTRZM, XTRZM) & 0,169450 & 0,003096 & 54,72333 & $0,0000 * * *$ \\
\hline & GARCH(XTRZM, USD) & 0,194901 & 0,004298 & 45,34544 & $0,0000 * * *$ \\
\hline & GARCH(USD, USD) & 0,224174 & 0,006208 & 36,11147 & $0,0000 * * *$ \\
\hline \multirow{7}{*}{ Model 2} & $\mathrm{M}$ & 0,012328 & 0,001902 & 6,481013 & $0,0000 * * *$ \\
\hline & ARCH(XTRZM, XTRZM) & 0,082249 & 0,006938 & 11,85410 & $0,0000 * * *$ \\
\hline & $\mathrm{ARCH}(\mathrm{XTRZM}, \mathrm{EUR})$ & 0,080103 & 0,005271 & 15,19644 & $0,0000 * * *$ \\
\hline & ARCH(EUR, EUR) & 0,078013 & 0,007214 & 10,81363 & $0,0000 * * *$ \\
\hline & GARCH(XTRZM, XTRZM) & 0,909334 & 0,006462 & 140,7208 & $0,0000 * * *$ \\
\hline & GARCH(XTRZM, EUR) & 0,911108 & 0,004768 & 191,0709 & $0,0000 * * *$ \\
\hline & GARCH(EUR, EUR) & 0,912886 & 0,006871 & 132,8549 & $0,0000 * * *$ \\
\hline \multirow{7}{*}{ Model 3} & $\mathrm{M}$ & 0,009369 & 0,001506 & 6,222769 & $0,0000 * * *$ \\
\hline & ARCH(XTRZM, XTRZM) & 0,089398 & 0,006274 & 14,24979 & $0,0000 * * *$ \\
\hline & $\mathrm{ARCH}(\mathrm{XTRZM}, \mathrm{JPY})$ & 0,064690 & 0,003861 & 16,75256 & $0,0000 * * *$ \\
\hline & $\mathrm{ARCH}(J P Y, J P Y)$ & 0,046811 & 0,004152 & 11,27404 & $0,0000 * * *$ \\
\hline & GARCH(XTRZM, XTRZM) & 0,923492 & 0,004150 & 222,5364 & $0,0000 * * *$ \\
\hline & GARCH(XTRZM, JPY) & 0,936583 & 0,002931 & 319,5428 & $0,0000 * * *$ \\
\hline & GARCH(JPY, JPY) & 0,949859 & 0,003661 & 259,4795 & $0,0000 * * *$ \\
\hline \multirow{7}{*}{ Model 4} & $\mathrm{M}$ & 0,020429 & 0,001024 & 19,95509 & $0,0000 * * *$ \\
\hline & ARCH(XTRZM, XTRZM) & 0,139135 & 0,004087 & 34,04702 & $0,0000 * * *$ \\
\hline & $\mathrm{ARCH}(\mathrm{XTRZM}, \mathrm{GBP})$ & 0,045952 & 0,001159 & 39,64165 & $0,0000 * * *$ \\
\hline & $\mathrm{ARCH}(\mathrm{GBP}, \mathrm{GBP})$ & 0,015176 & 0,000539 & 28,14309 & $0,0000 * * *$ \\
\hline & GARCH(XTRZM, XTRZM) & 0,888522 & 0,002612 & 340,1545 & $0,0000 * * *$ \\
\hline & GARCH(XTRZM, GBP) & 0,926174 & 0,001680 & 551,2514 & $0,0000 * * *$ \\
\hline & $\mathrm{GARCH}(\mathrm{GBP}, \mathrm{GBP})$ & 0,965422 & 0,001590 & 607,0039 & $0,0000 * * *$ \\
\hline \multirow{7}{*}{ Model 5} & $\mathrm{M}$ & 0,014263 & 0,002867 & 4,975173 & $0,0000 * * *$ \\
\hline & $\mathrm{ARCH}(\mathrm{XTRZM}, \mathrm{XTRZM})$ & 0,018906 & 0,002703 & 6,993374 & $0,0000 * * *$ \\
\hline & $\mathrm{ARCH}(\mathrm{XTRZM}, \mathrm{RUB})$ & 0,064433 & 0,006295 & 10,23509 & $0,0000 * * *$ \\
\hline & $\mathrm{ARCH}(\mathrm{R} \cup \mathrm{B}, \mathrm{RUB})$ & 0,219589 & 0,024498 & 8,963478 & $0,0000 * * *$ \\
\hline & GARCH(XTRZM, XTRZM) & 0,975796 & 0,002622 & 372,1695 & $0,0000 * * *$ \\
\hline & GARCH(XTRZM, RUB) & 0,893967 & 0,008538 & 104,7014 & $0,0000 * * *$ \\
\hline & GARCH(RUB, RUB) & 0,818999 & 0,014933 & 54,84388 & $0,0000 * * *$ \\
\hline
\end{tabular}

Diagonal VECH GARCH modeli sonuçları incelendiğinde, Model 1, Model 2, Model 3 ve Model 4'te XTRZM endeksi getiri serilerine ilişkin ARCH parametreleri, döviz kuru serilerine ilişkin ARCH parametrelerinden yüksek çıkmıştır. Dolayısıyla, söz konusu modellerde ele alınan farklı dönemler itibariyle BIST XTRZM endeksi getirilerinde meydana gelen bir şokun şiddetinin, USD, EUR, JPY ve GBP döviz kuru serilerinde meydana gelen bir şokun şiddetinden daha büyük olduğu söylenebilir. Model 5'e ilişkin sonuçlar ise, RUB döviz kuru serisine ilişkin ARCH parametresinin, XTRZM endeksi getiri serisine ilişkin ARCH parametresinden yüksek olduğunu göstermektedir. Bu durumda, RUB döviz kuru serisinde meydana gelen bir şokun şiddetinin, XTRZM endeksi getiri serisinde meydana gelen bir şokun şiddetinden daha büyük olduğu söylenebilir. Modellerde yer alan değişkenlere ilişkin GARCH parametreleri incelendiğinde ise, Model 1, Model 2, Model 3 ve Model 4'te döviz kuru serilerine ilişkin GARCH parametrelerinin, BiST XTRZM endeksi getiri serilerine ilişkin GARCH parametrelerinden yüksek olduğu görülmektedir. Dolayısıyla, söz konusu modellerde ele alınan farklı dönemler itibariyle USD, EUR, JPY ve GBP döviz kurlarında meydana gelen şokların etkilerinin, XTRZM endeksi getirilerinde meydana gelen şokların etkilerine kıyasla daha kalıcı olduğu ve uzun hafıza etkisi gösterdiği söylenebilir. Model 5'e ilişkin sonuçlarda ise, XTRZM endeksi getiri serisine ilişkin GARCH parametresinin, RUB döviz kuru serisine ilişkin GARCH parametresinden yüksek olduğu görülmektedir. Bu durumda, XTRZM endeksi getirilerinde meydana gelen şokların etkilerinin, RUB döviz 
kurunda meydana gelen şokların etkilerine kıyasla daha kalıcı olduğu ve uzun hafıza etkisi gösterdiği söylenebilir.

Ortak ARCH ve GARCH parametreleri değişkenler arasındaki ortak varyans hakkında bilgi vermekte ve parametrelere ilişkin katsayılar toplamının 1'den küçük, pozitif ve anlamlı olması değişkenler arasındaki volatilite yayılım etkisini ifade etmektedir. Diagonal VECH GARCH modeli sonuçlarına göre, tüm modellerde ortak ARCH ve GARCH parametreleri katsayıları pozitif ve anlamlıdır. Sonuçlara göre, Model 1 , Model 2, Model 4 ve Model 5'te yer alan ortak $A R C H$ ve GARCH parametreleri katsayıları toplamları 1'den küçük çıkmıştır. Analiz sonucunda, USD, EUR, GBP ve RUB döviz kurlarından XTRZM endeks getirilerine doğru pozitif volatilite yayılım etkisinin olduğunu ve bu etkinin uzun hafıza özelliği gösterdiği tespit edilmiştir. Model 3'e ilişkin ortak ARCH ve GARCH parametreleri toplamı 1'den büyük elde edildiğinden JPY döviz kurundan XTRZM endeks getirilerine doğru anlamlı bir volatilite yayılım etkisinin bulunmadığı söylenebilir.

Şekil 2'de yer alan Model 1, Model 2, Model 3, ve Model 4'e ilişkin bireysel varyans grafikleri incelendiğinde, dört modelde ele alınan dönemlerde de XTRZM endeksi getiri serilerinin döviz kuru serilerine kıyasla sisteme gelen şoklara daha yüksek tepki gösterdiği görülmektedir. Model 5'te ise bu durumun tersi söz konusudur. Bireysel varyans grafikleri, Şekil 1'de yer alan değişkenlere ilişkin getiri grafiklerinde tespit edilen volatilite kümelenmelerini ve Tablo 3'te yer alan standart sapma değerlerini desteklemektedir. Model 1, Model 2 Model 3 ve Model 4'e ilişkin kovaryans grafikleri incelendiğinde ise, ortak varyansın 2001 ŞubatMart döneminde yüksek düzeyde ve pozitif yönde oynaklık sergilediği, 2001 Eylül, 2008 Ekim-Kasım ve 2018 Ağustos dönemlerinde ise yüksek düzeyde negatif oynaklık sergilediği görülmektedir. Söz konusu modellerde ilgili dönemlerde volatilite yayılım etkilerinin yükseldiği söylenebilir. Model 5'e ilişkin kovaryans grafiği incelendiğinde ise, ortak varyansın 2011 Ağustos, 2013 Aralık, 2015 Mayıs-Haziran ve 2018 Ağustos-Eylül dönemlerinde yüksek düzeyde pozitif yönde, 2015 Şubat, 2016 Temmuz ve 2018 Mayıs-Haziran dönemlerinde yüksek düzeyde negatif yönde oynaklık sergilediği söylenebilir.

Şekil 2. Değiş̧kenlere iliş̧kin Varyans ve Kovaryans Grafikleri
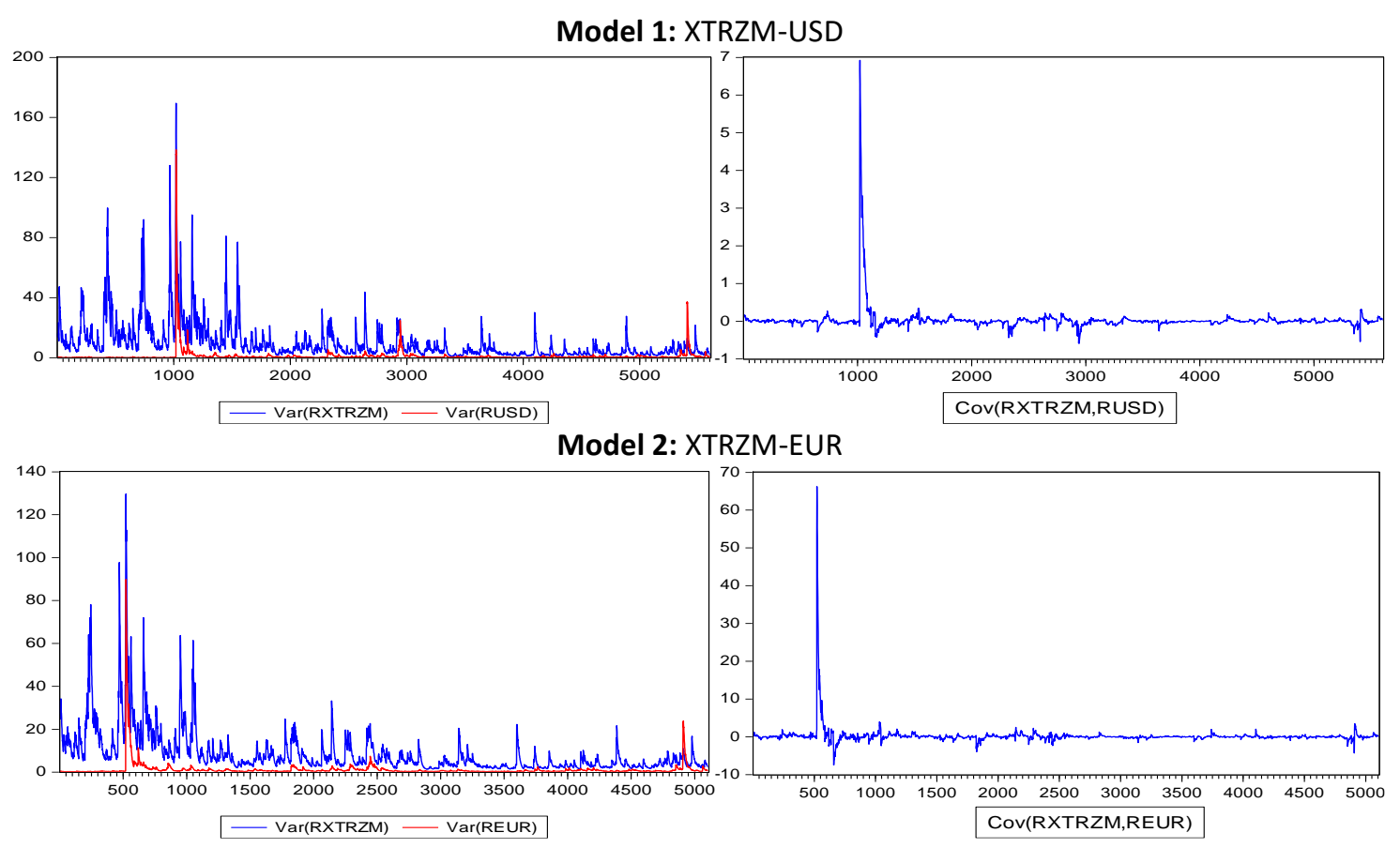
Şekil 2. Değişkenlere İlişkin Varyans ve Kovaryans Grafikleri (Devam)

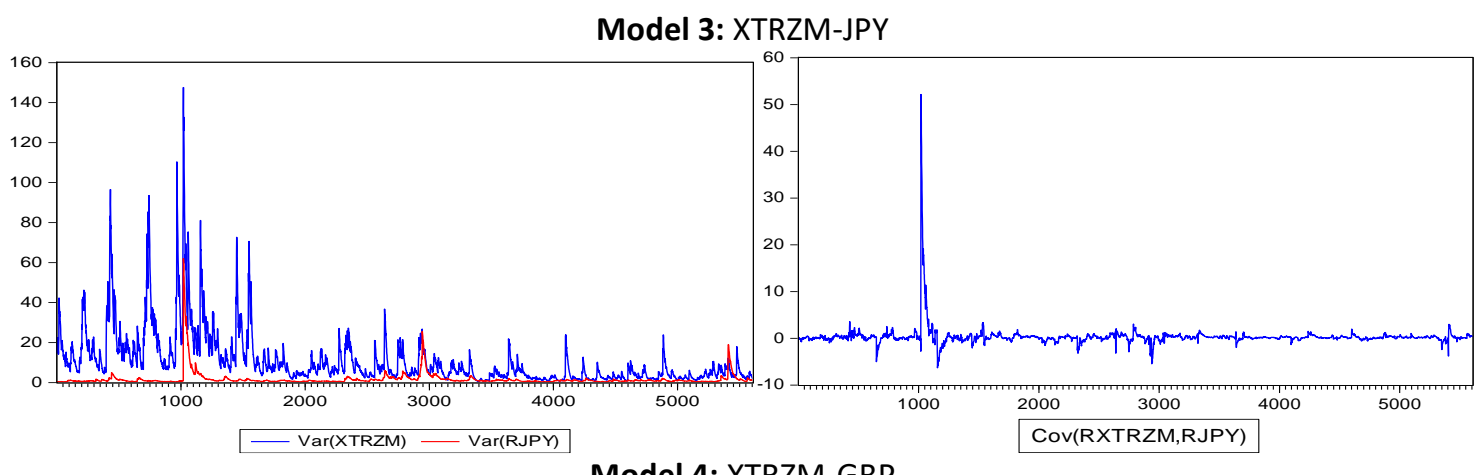

Model 4: XTRZM-GBP

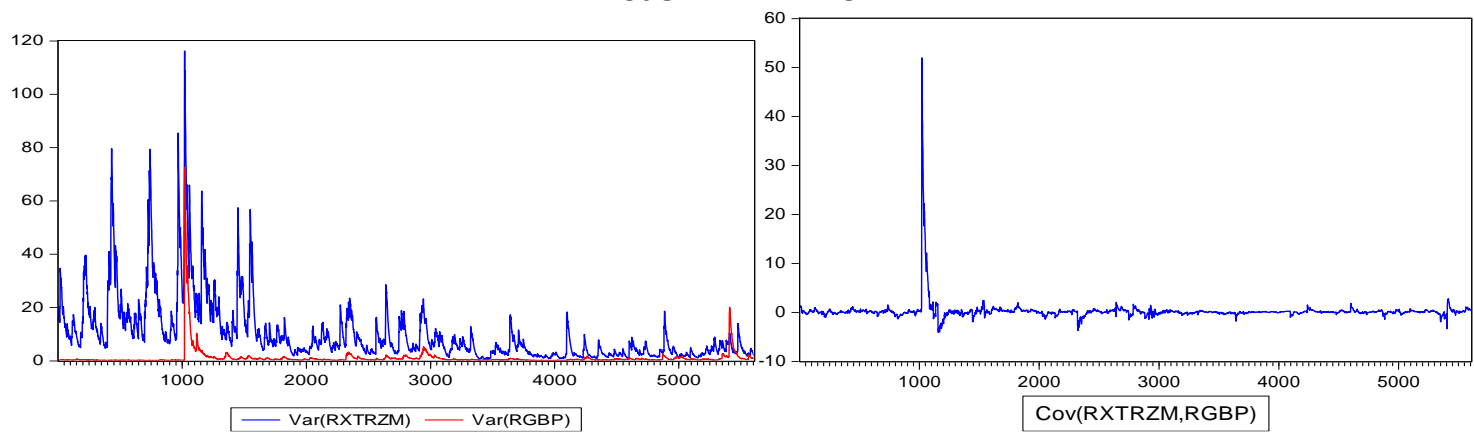

Model 5: XTRZM-RUB

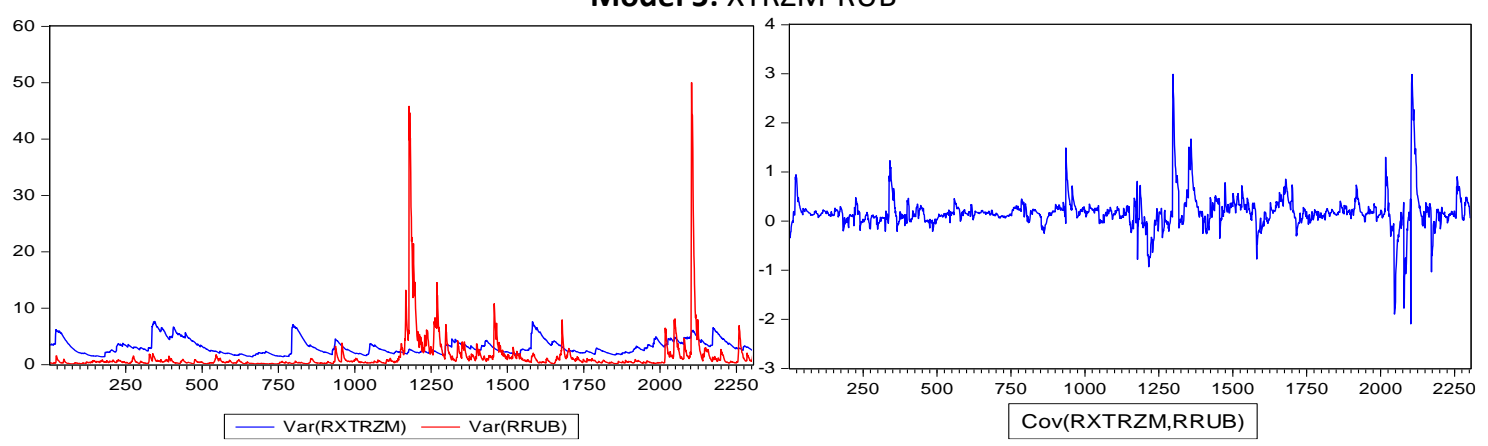

Oluşturulan modellerin hata terimlerinde otokorelasyon ve değişen varyansın olup olmadığının tespit edilebilmesi için hesaplanan Ljun-Box $Q$ ve $Q^{2}$ istatistikleri Tablo 7'de yer almaktadır.

Ljun-Box $Q$ ve $Q^{2}$ istatistiklerinin herhangi bir anlamlılık düzeyindeki kritik değerden düşük olması, ilgili anlamlılık düzeyinde test olasılı̆ının anlamsız olması anlamına gelmektedir. Dolayısıyla $Q$ ve $Q^{2}$ istatistiklerinin kritik değerlerden düşük olması, ilgili anlamlılık düzeyinde modelde otokorelasyon ve değişen varyansın yokluğunu ifade eden temel hipotezin reddedilemeyeceği anlamına gelmektedir. Tablo 7'de incelendiğinde modellere ilişkin hesaplanan Ljun-Box $Q$ ve $Q^{2}$ istatistiklerinin neredeyse tüm serbestlik derecelerinde $\% 1, \% 5$ ve $\% 10$ anlamlılık düzeylerinde kritik değerlerden düşük gerçekleştikleri tespit edilmiştir. Dolayısıyla modellerde otokorelasyon ve değişen varyans sorunlarının olmadığı ve model spesifikasyonlarının doğru olduğu söylenebilir. 
Tablo 7. Serilere Illişkin Değişen Varyans ve Otokorelasyon Test Sonuçları

\begin{tabular}{|c|c|c|c|c|c|c|}
\hline \multicolumn{7}{|c|}{ ARCH-LM Testi } \\
\hline Modeller & $\begin{array}{c}\text { Serbestlik } \\
\text { Derecesi (Df) }\end{array}$ & $1 \mathrm{Df}$ & $5 \mathrm{Df}$ & $10 \mathrm{Df}$ & $20 \mathrm{Df}$ & $30 \mathrm{Df}$ \\
\hline \multirow{2}{*}{ Model 1} & $\mathbf{Q}$ & 2,11 & 9,24 & 14,48 & 23,43 & 38,79 \\
\hline & $\mathbf{Q}^{2}$ & 1,35 & 8,84 & 13,75 & 19,71 & 36,25 \\
\hline \multirow{2}{*}{ Model 2} & $\mathbf{Q}$ & 1,02 & 8,38 & 11,34 & 25,28 & 39,45 \\
\hline & $\mathbf{Q}^{2}$ & 0,95 & 9,13 & 10,90 & 22,41 & 38,62 \\
\hline \multirow{2}{*}{ Model 3} & $\mathbf{Q}$ & 0,99 & 7,46 & 16,52 & 20,25 & 31,47 \\
\hline & $\mathbf{Q}^{2}$ & 1,16 & 7,94 & 14,43 & 23,49 & 33,97 \\
\hline \multirow{2}{*}{ Model 4} & $\mathbf{Q}$ & 2,68 & 8,52 & 12,73 & 27,18 & 40,12 \\
\hline & $\mathbf{Q}^{2}$ & 2,72 & 9,36 & 10,67 & 26,71 & 37,42 \\
\hline \multirow{2}{*}{ Model 5} & $\mathbf{Q}$ & 2,08 & 6,42 & 13,82 & 25,87 & 31,56 \\
\hline & $Q^{2}$ & 1,95 & 7,81 & 12,04 & 26,45 & 34,77 \\
\hline \multicolumn{7}{|c|}{ Serbestlik Derecelerine ve Anlamlılık Düzeylerine Göre Kritik Değerler } \\
\hline \multicolumn{2}{|c|}{$\begin{array}{l}\text { Anlamlılık Düzeyleri / } \\
\text { Serbestlik Dereceleri }\end{array}$} & $1 \mathrm{Df}$ & $5 \mathrm{Df}$ & $10 \mathrm{Df}$ & $20 \mathrm{Df}$ & $30 \mathrm{Df}$ \\
\hline \multicolumn{2}{|c|}{$\% 1$} & 6,63490 & 15,08627 & 23,20925 & 37,56623 & 50,89218 \\
\hline \multicolumn{2}{|c|}{$\% 5$} & 3,84146 & 11,07050 & 18,3070 & 31,41043 & 43,77297 \\
\hline \multicolumn{2}{|c|}{$\% 10$} & 2,70554 & 9,23636 & 15,98718 & 28,41198 & 40,25602 \\
\hline
\end{tabular}

\section{Sonuç}

Döviz kuru ve pay piyasası arasındaki ilişki üzerine geliştirilmiş olan geleneksel yaklaşım, döviz kurlarında meydana gelen yükselişlerin, firmaların rekabetçiliklerini ve ihracatlarını artıracağını, dolayısıyla firmaların gelir düzeyleri ve pay fiyatlarının da yükseleceği temel düşüncesine dayanır. Geleneksel yaklaşım turizm sektörü için düşünüldüğünde, yerli paranın değerinde meydana gelen düşüşlerin yabancı turistleri cezbedeceği ve yabancı turist sayısı ve turizm gelirlerinde artış meydana geleceği söylenebilir. Bu yaklaşım, döviz piyasalarında meydana gelen şokların pay piyasalarına da yansıyacağı, dolayısıyla iki piyasa arasındaki volatilite yayılım etkisinin döviz piyasalarından pay piyasalarına doğru olacağını ifade etmektedir. Bu çalışmada, döviz kurları ile BiST Turizm Endeksi (XTRZM) getirileri arasındaki volatilite yayılım etkisinin ekonometrik yöntemlerle belirlenmesi amaçlanmıştır. Bu amaç doğrultusunda, konvertibilitesi yüksek para birimleri olan USD, EUR, JPY ve GBP ve Türkiye'ye yüksek miktarda turist gönderen ülkelerden biri olan Rusya'nın para birimi olan RUB döviz kurları çalışma kapsamına alınmıştır. Çalışmada döviz kurları ile XTRZM endeksi getirileri arasındaki volatilite yayılım etkileri çok değişkenli GARCH modellerinden olan Diagonal VECH-GARCH yöntemi ile analiz edilmiştir. Çalışmada turizm endeksi getirilerine farklı döviz kurlarından volatilite yayılımlarının ve aralarındaki farklılıkların incelenmesi açısından çalışmanın özgünlük sunduğu ve ilgili literatüre katkı sağlayacağı düşünülmektedir.

Çalışmada uygulanan Diagonal VECH GARCH modelinden elde edilen bulgulara göre, BiST XTRZM endeksi getirilerinde meydana gelen bir şokun şiddetinin, USD, EUR, JPY ve GBP döviz kuru serilerinde meydana gelen bir şokun şiddetinden daha büyük olduğu, RUB döviz kuru serisinde meydana gelen bir şokun şiddetinin ise, XTRZM endeksi getiri serisinde meydana gelen bir şokun şiddetinden daha büyük olduğu söylenebilir. Bu bulgular, piyasalarda meydana gelen beklenmedik olayların turizm firmalarının pay getirilerini ani ve önemli ölçüde etkilediğini, sektörün piyasaya gelen şoklara karşı yüksek düzeyde duyarlı olduğunu ifade etmektedir. USD, EUR, JPY ve GBP döviz kurlarında meydana gelen şokların etkilerinin, XTRZM endeksi getirilerinde meydana gelen şokların etkilerine kıyasla daha kalıcı olduğu ve uzun hafıza etkisi gösterdiği, XTRZM endeksi getirilerinde meydana gelen şokların etkilerinin ise, RUB döviz kurunda meydana gelen şokların etkilerine kıyasla daha kalıcı olduğu ve uzun hafıza etkisi gösterdiği söylenebilir. Bu durumda, Türkiye'de turizm sektörünün piyasaya gelen şokları döviz piyasasına nazaran daha kısa sürede atlayabildiği söylenebilir. Analiz sonucunda, USD, EUR, GBP ve RUB döviz kurlarından XTRZM endeks getirilerine doğru pozitif volatilite yayılım etkisinin olduğunu ve bu etkinin uzun hafıza özelliği gösterdiği, JPY döviz kurundan 
XTRZM endeks getirilerine doğru anlamlı bir volatilite yayılım etkisinin ise olmadığı tespit edilmiştir. Bu bağlamda, döviz kurlarının turizm endeksi getirilerinin, dolayısıyla turizm firmalarının pay fiyatlarındaki dalgalanmaların belirleyicilerinden biri olduğunu söylemek mümkündür. Bu sonuç, döviz kurlarının Türkiye'de turizm sektöründe faaliyet gösteren firmalara yapılacak pay yatırımlarında dikkat edilmesi gereken önemli bir değişken olduğunu ortaya koymaktadır. Özellikle yatırım yapılması düşünülen turizm firmalarının faaliyet türleri, hangi ülkelerden ne miktarda müşteriye sahip oldukları, geçmiş dönem pay getirileri ile döviz kurları arasındaki ilişkileri gibi faktörlerin değerlendirilmesinin yatırım kararı açısından faydalı olacağı düşünülmektedir.

Çalışma bulgularına göre yapılabilecek diğer bir yorum ise hem döviz kuru volatilitesi hem turizm endeksi getiri volatilitesi hem de iki piyasa arasındaki volatilite yayılım etkilerinin ekonomik-finansal krizler ve ülkeler arası politik gelişmeler gibi piyasaların kendilerine özgü olmayan ve ortadan kaldıramayacakları faktörlerden yüksek düzeyde etkilendikleri şeklindedir. Edilen bulgular, özellikle döviz kurlarındaki oynaklığın artığı dönemlerde turizm endeksi getirilerinde de volatilitenin yükseldiğine işaret etmektedir. Çalışma sonucunda elde edilen bulgular, Darbar ve Deb (1999), Apte (2001), Bodart ve Reding (2001), Erdem vd. (2005), Adjasi vd. (2008), Beer ve Hebein (2008), Raghavan ve Dark (2008), O’Donnell ve Morales (2009), Fedorova ve Saleem (2010), Okpara ve Odionye (2012), Kang ve Yoon (2013), Mozumder vd. (2015), Akkaş ve Sayılgan (2016), Aktaş vd. (2018) ve Yamak vd. (2018) çalışmaları ile benzerlik göstermektedir. Çalışma sonuçlarının, turizm endeksi ve turizm firmaları pay yatırımcıları başta olmak üzere, araştırmacılar ve analistler gibi farklı çevrelerden ilgililere risk yönetimi ve yatırım kararları alma konularında fayda sağlayacağı düşünülmektedir. Çalışmanın sonuçları değerlendirilirken çalışmanın ele alınan dönemle itibariyle kısıtlara sahip olduğu ve kurulan modellerin kriz dönemlerini kapsadığı unutulmamalıdır.

\section{Beyan ve Açıklamalar (Disclosure Statements)}

1. Bu çalışmanın yazarları, araştırma ve yayın etiği ilkelerine uyduklarını kabul etmektedirler (The authors of this article confirm that their work complies with the principles of research and publication ethics).

2. Yazarlar tarafından herhangi bir çıkar çatışması beyan edilmemiştir (No potential conflict of interest was reported by the authors).

3. Bu çalışma, intihal tarama programı kullanılarak intihal taramasından geçirilmiştir (This article was screened for potential plagiarism using a plagiarism screening program).

\section{Son Notlar}

1. Bu araştırma, 16-17 Kasım 2019 tarihleri arasında Balıkesir'de düzenlenen "International Conference on Applied Economics and Finance \& Extended with Social Sciences (ICOAEF'VI)" isimli konferansta sözlü olarak sunulmuş ve özet olarak yayımlanmıştır.

\section{Kaynaklar}

Adjasi, C., Harvey, S. K., \& Agyapong, D. (2008). Effect of exchange rate volatility on the Ghana Stock Exchange. African Journal of Accounting, Economics, Finance and Banking Research, 3(3), 28-47.

Akar, C. (2012). Modeling Turkish tourism demand and the exchange rate: The bivariate GARCH approach. European Journal of Economics, Finance and Administrative Sciences, 50, 133-141.

Akkaş, M. E., \& Sayılgan, G. (2016). Volatility spillover between foreign exvhange and stock markets: Evidence from Turkey. 20. Finans Sempozyumu, Karadeniz Teknik Üniversitesi, Trabzon.

Aktaş, H., Kayalıdere, K., \& Karataş Elçiçek, Y. (2018). Petrol, dolar kuru ve hisse senedi piyasası arasındaki ortalamaoynaklık yayılım etkisi: BísT100 üzerine bir uygulama. Muhasebe ve Vergi Uygulamaları Dergisi, Nisan Özel Sayı, 354-377.

Alkan, B., \& Çiçek, S. (2020). Spillover effect in financial markets in Turkey. Central Bank Review, 1-12. 
Apte, P. (2001). The Interrelationship between stock markets and the foreign exchange market. Prajnan, 30, 17-29.

Bahar, O. (2007). Türkiye'deki devalüasyon uygulamalarının turizm sektörü üzerindeki etkisi. Süleyman Demirel Üniversitesi IiBF Dergisi, 12(1), 255-272.

Beer, F., \& Hebein, F. (2008). An assessment of the stock market and exchange rate dynamics in industrialized and emerging markets. Intenational Business \& Economics Research Journal, 7(8), 59-70.

Bodart, V., \& Reding, P. (2001). Do foreign exchange markets matter for industry stock returns? An ampirical investigation. Discussion Papers (IRES-Institut de Recherches Economiques et Sociales), 2001016. https://sites.uclouvain.be/econ/DP/IRES/2001-16.pdf (Erişim Tarihi: 15 Aralık 2019).

Bollersev, T., Engle, R. F., \& Wooldridge, J.M. (1988). A capital asset pricing model with time-varying covariances. Journal of Political Economy, 96(1), 116-131.

Branson, W. H. (1981). Macroeconomic determinants of real exchange rates. NBER Working Paper, 801.

Crouch, G. I. (1994). The study of international tourism demand: A review of findings. Journal of Travel Research, 33(1), 12-13.

Çelik Oğuz, S., \& Topbaş, F. (2011). Döviz kuru oynaklığı turizm talebi ilişkisi: 1990-2010 Türkiye örneği. EconAnadolu 2011: Anadolu International Conference in Economics II, 15-17 Haziran, Eskişehir.

Çiçek, M. (2010). Türkiye'de faiz, döviz ve borsa: Fiyat ve oynaklık yayılma etkileri. Ankara Üniversitesi SBF Dergisi, 65(2), $1-28$.

Çil Yavuz, N. (2015). Finansal ekonometri (2. Basım). İstanbul: Der Yayınları.

Darbar, S. M., \& Deb, P. (1999). Linkages among asset markets in the United States: Tests in a bivariate GARCH framework. IMF Working Papers, WP/99/158, International Monetary Fund.

Demirel, B., Bozdağ, E. G., \& Inci, A. G. (2008). Döviz kurlarındaki dalgalanmaların gelen turist sayısına etkisi: Türkiye örneği. Dokuz Eylül Üniversitesi Ulusal Iktisat Kongresi, İzmir. https://www.researchgate.net/profile/Baki_Demirel/publication/242414248_DOVZ_KURLARINDAKDALGALAN MALARIN_GELEN_TURST_SAYISINA_ETKS_TURKYE_ORNE/links/599ac52aa6fdcc26158875d4/DOeVZKURLARINDAKDALGALANMALARIN-GELEN-TURST-SAYISINA-ETKS-TUERKYE-OeRNE.pdf （Erişim Tarihi: 19.05.2020)

Dickey, D. A., \& Fuller, W. A. (1979). Distribution of estimators for autoregressive time series with a unit root. Journal of the American Statistical Association, 74, 427-431.

Dornbusch, R., \& Fischer, S. (1980). Exchange rates and current account. The American Economic Review, 70(5), 960971.

Dritsakis, N. (2004). Tourism as a long-run economic growth factor: An ampirical investigation for Greece using causality analysis. Tourism Economics, 10, 305-316.

Eilat, Y., \& Einav, L. (2004). Determinants of international tourism: A three-demensional panel data analysis. Applied Economics, 36, 1315-1327.

Engle, R. F., \& Kroner, K. F. (1995). Multivariate simultaneous Generalized ARCH. Econometric Theory, 11, $122-150$.

Erdem, C., Arslan, C. K., \& Erdem, M. S. (2005). Effects of macroeconomic variables on Istanbul stock exchange indexes. Applied Financial Economics, 15, 987-994.

Erdoğan, S., \& Bozkurt, H. (2009). Türkiye'de cari açığın belirleyicileri: MGARCH modelleri ile bir inceleme. Maliye ve Finans Yazıları, 84, 135-172.

Eugenio-Martin, J. L., Morales, N. M., \& Scarpa, R. (2004). Tourism and economic growth in Latin American countries: A panel data approach. Nota Di Lavoro, 26, 1-28.

Federova, E., \& Saleem, K. (2010). Volatility spillovers between stock and currency markets: Evidence from emerging Eastern Europe. Czech Journal of Economics and Finance, 60 (6), 519-533.

Gökbulut, R. I. (2017). An ampirical analysis of volatility transmission between BIST and international stock markets. Ekonomik ve Sosyal Yaklaşımlar Dergisi, 13(1), 141-159.

İçöz, O., Var, T., \& Kozak, M. (1998). Tourism demand in Turkey. Annals of Tourism Research, 25(1), 236-240.

Kanas, A. (2000). Volatility spillovers between stock returns and exchange rate changes: International evidence. Journal of Business Finance \& Accounting, 27(3), 447-467.

Kang, S. H., \& Yoon, S. M. (2013). Revisited return and volatility spillover effect in Korea. Korea and the World Economy, $14(1), 121-145$. 
Kaya, V., \& Çakır Çömlekçi, S. (2013). Döviz kuru oynaklığının turizm sektörüne etkileri: Türkiye örneği (2002-2011). Seyahat ve Otel İ̧̧letmeciliği Dergisi, 10(2), 82-89.

Kwiatkowski, D., Phillips, P. C. B., Schmidt, P., \& Shin, Y. (1992). Testing the null hypotesis of stationary against the alternative of a unit root: How sure are we that economic time series have a unit root? Journal of Econometrics, 54(1-3), 159-178.

Ljung, G. M., \& Box, G. E. P. (1978). On a measure of lack of fit in time series models. Biometrika, 62(2), 297-303.

Mervar, A., \& Payne, J. E. (2007). Analysis of foreign tourism demand for Crotian destinations: Long-run elasticity estimates. Tourism Economics, 13, 407-420.

Mozumder, N., De Vita, G., Kyaw, K.S., \& Larkin, C. (2015), Volatility spillover between stock prices and exchange rates: New evidence across the recent financial crisis period. Economic Issues, 20(1), 43-64.

Narayan, P. K. (2008). Exemaning the behaviour of visitor arrivals to Australia from 28 different countries. Transportation Research Part A: Policy and Practice, 42(5), 751-761.

O'Donnell, M., \& Morales, L. (2009). Volatility spillovers between stock returns and foreign exchange rates: Evidence from four Eastern European countries. International Journal of Business, 12, 1-20.

Okpara, G. C., \& Odionye, J. C. (2012). The direction of volatility spillover between stock prices and exchange rate: Evidence from Nigeria. Elixir Finance, 42, 6410-6414.

Öncel, A., İnal V., \& Torusdağ, M. (2016). Türkiye'de reel döviz kuru-turizm gelirleri ilişkisi: 2003-2015 dönemi için ampirik bir uygulama. Yüzüncü Yıl Üniversitesi Iktisadi ve Idari Bilimler Fakültesi Dergisi, (2), 125-142.

Özmen, A., \& Poyraz, K. (1999). Zaman serilerini mevsimlik etkiden arındırmada uygun tekniğin belirlenmesine ilişkin bir yaklaşım. Dumlupınar Üniversitesi Sosyal Bilimler Fakültesi, 3, 167-186.

Patsouratis, V., Frangouli, Z., \& Anastasopoulus, G. (2005). Competition in tourism among the mediterranean countries. Applied Economics, 37, 1865-1870.

Phillips, P. C. B., \& Perron, P. (1988). Testing for a unit root in time series regression. Biometrika, 75, 335-346.

Raghavan, M. V., \& Dark, J. (2008). Return and volatility spillovers between the foreign exchange market and the Australian all ordinaries index. The IUP Journal of Applied Finance, 14(1), 41-48.

Seyidoğlu, H. (2009). Uluslararası iktisat, teori, politika ve uygulama. İstanbul: Güzem Can Yayınevi.

Songül, H. (2010). Otoregresif koşullu değişen varyans modelleri: Döviz kurları üzerine uygulama. Uzmanlık Yeterlilik Tezi, TCMB Araştırma ve Para Politikası Genel Müdürlüğü, Ankara.

Şen, A., \& Şit, M. (2015). Reel döviz kurunun Türkiye'nin turizm gelirleri üzerindeki etkisinin ampirik analizi. Journal of Yasar University, 10(40), 6752-6762.

Toh, R. S., Khan, H., \& Ng, F. T. (1997). Prospects fort he tourism and hotel industry in Singapore: A regression model. Cornell Hotel and Restaurant Administration Quarterly, 3, 80-87.

Topaloğlu, E. E. (2019). CBOE VIX Endeksi ile OECD ülke borsaları arasındaki volatilite yayılımı: CCC-MGARCH modeli ile ampirik bir araştırma. Ankara Hacı Bayramı Veli Üniversitesi Iktisadi ve Idari Bilimler Fakültesi Dergisi, 21(3), 574595.

Topaloğlu, E. E. (2020). Borsa İstanbul pay endekslerinin volatilite yapısı ve volatilite yayılımı: GARCH ve MGARCH modelleri ile BIST Sınai ve Mali Endeksleri örneği. Dumlupınar Üniversitesi Sosyal Bilimler Dergisi, 63, 17-38.

Webber, A. (2011). Exchange rate volatility and cointegration in tourism demand. Journal of Travel Research, 39, 398405.

Yamak, N., Kolcu, F., \& Köyle, F. (2018). Döviz kuru oynaklığı ve borsa endeks oynaklığı arasındaki asimetrik ilişki. Balkan Journal of Social Sciences, 7(14), 171-187.

Yıldız, B. (2016). Oynaklık tahmininde simetrik ve asimetrik GARCH modellerinin kullanılması: seçilmiş BiST Alt Sektör Endeksleri üzerine bir uygulama. Muhasebe ve Finansman Dergisi, (72), 83-106.

Yung Yang, S., \& Chyi Doong, S. (2004). Price and volatility spillovers between stock prices and exchange rates: Empirical evidence from the G-7 countries. International Journal of Business and Economics, 3(2), 139-153.

Türkiye İstatistik Kurumu, Turizm İstatistikleri, Sınır İstatistikleri, http://www.tuik.gov.tr/PreTablo.do?alt_id=1072 adresinden 15.12.2019 tarihinde alınmıştır.

Turizm ve Kültür Bakanlı̆̆ı, Turizm İstatistikleri, Sınır İstatistikleri, Yıllık Bültenler, https://yigm.ktb.gov.tr/TR249709/yillik-bultenler.html adresinden 15.12.2019 tarihinde alınmıştır. 